\title{
Changes in the external costs of freight surface transport In Spain
}

\author{
P.J. Pérez-Martínez ${ }^{\mathrm{a}, *}$, J.M. Vassallo-Magro ${ }^{\mathrm{b}}$ \\ a Sustainable Economy of Natural Environment Group (ECSEN), Universidad Politécnica de Madrid, C/Ramiro de Maeztu s/n, 28040 Madrid, Spain \\ ${ }^{\mathrm{b}}$ Transport Research Centre (TRANSyT), C/Profesor Aranguren s/n, 28040 Madrid, Spain
}

Keywords:

Externalities

Freight transport

Trends

Fundamental factors

Vehicle technology

\begin{abstract}
A B S T R A C T
This paper studies the external costs of surface freight transport in Spain and finds that a reduction occurred over the past 15 years. The analysis yields two conclusions: trucks have experienced a reduction in external costs, and rail has lower externalities. The external costs of road freight transport decrease between 1993 and 2007 (44\%). The external costs of rail freight increase by 12\%. During this period, the external costs of road freight related to climate increase by $16 \%$, oppositely than those from air pollution and accidents (51 and 44\%). The external costs of rail related to pollutant emissions and climate increase by $4 \%$ and $43 \%$. Oppositely, the external costs related to accidents decrease by $27 \%$. Road freight generates eight times the external costs of rail, 2.35 Euro cents per tonne kilometre in 2005 (5.6\% accidents, 74.7\% air pollution and $19.7 \%$ climate) vs. 0.28 (13.4\% accidents, $53.9 \%$ air pollution and $32.7 \%$ climate).
\end{abstract}

\section{Introduction}

The large growth in passenger and freight transport that has occurred across all parts of the globe in the past couple decades has led to increased the need to minimise transport's external costs, such as emissions, accidents and noise (Lenz, Prüller, \& Gruden, 2003; Singh et al., 2008). In this context, the external costs of freight road transport - which is the main mode of transport in terms of tonne-kilometres, kilometres travelled, the value of goods shipped, or expenditure - are being reduced. For instance, truck manufacturers are reducing the energy consumption and related pollutant emissions per vehicle-kilometre travelled (Berg, 2003). The external costs generated by transport have been widely researched in recent years. In fact, there are many methodologies and studies on the subject (Forkenbrock, 1999; Lemp \& Kockelman, 2008; Quinet, 2004). The EU has recently prepared the Handbook on estimation of external costs to serve as a basis for establishing the externalities avoided as a result of modal substitution (Maibach et al., 2008). The Handbook can serve as a basis for establishing prices for the use of infrastructure in EU countries. However, arriving at a true estimate of the external costs attributed to each mode of transport in each situation remains the real challenge (Bickel, Friedrich, Link, Stewart, \& Nash, 2005).

\footnotetext{
* Corresponding author.

E-mail addresses: pjperez@caminos.upm.es (P.J. Pérez-Martínez), jvassallo@ caminos.upm.es (J.M. Vassallo-Magro).
}

The European pricing policy, its applications and the results of the research studies conducted in the European context highlight the importance of internalising the external costs and highlight the need to consider marginal social costs in infrastructure pricing (UE, $1995,1998 a, 1999,2006)$. This internalisation can affect all modes of transport in line with the external costs that they generate, and it can take into account all of the circumstances involved in the costs generated (ECMT, 2007; EEA, 2006; UE, 1998b, 2001). External costs are difficult to estimate and assess in economic terms, as is evident from the significant discrepancies in the evaluation results of numerous studies and projects conducted in Europe (AFFORD, 2001; GRACE, 2006; HEATCO, 2005; INFRAS-IWW, 2004; Monzón, Fernández, \& Jordá, 2007; UNITE, 2003). It is difficult to estimate such costs because they depend on specific variable factors that present a large degree of uncertainty. However, policies aimed at internalising and reducing the external costs, such as Directive 2006/38/EC (European Council, 2006), are based on accurately establishing the external costs - that are appropriate for each case, mode of transport and country in order to establish the general principles of infrastructure pricing for vehicles using such infrastructure in the EU (Link \& Nilsson, 2005; Nash, 2007; Nash \& Mathews, 2005; Rothengatter, 2001).

In Spain, there have been earlier studies focussing on the estimation of costs related to surface freight transport emissions, $\mathrm{CO}_{2}$ and pollutants (Aparicio et al., 2005; Betancor \& Nombela, 2003). However, there are no specific studies that analyse the trend of the external costs and evaluate the work that each mode of individual freight transport has performed, to reduce the externalities and 
Table 1

Studies of external costs in the EU.

\begin{tabular}{ll}
\hline Title & $\begin{array}{l}\text { Acronym/ } \\
\text { authors }\end{array}$ \\
\hline $\begin{array}{l}\text { Concerted Action } \\
\text { on Transport }\end{array}$ & CAPRI \\
Pricing Research & \\
Integration & \\
& \\
Real Cost Reduction & RECORDIT \\
of Door-To- Door & \\
Intermodal Transport & \\
Acceptability of Fiscal & AFFORD \\
Measures \& & \\
Organizational & \\
Requirements for & \\
Demand Management & \\
Unification of accounts & UNITE \\
and marginal costs & \\
for Transport Efficiency &
\end{tabular}

External costs

A meta-analysis
of western
European external
cost estimates

Developing Harmonized for transport costing and project assessment of transport European Approaches

Year $\quad$ Purpose and content

1998

An assessment of

European research projects on transport infrastructure pricing models from the 4 th European R\&D framework programme.

1998-2001 The fostering of intermodal costs in Europe. 2001 An assessment of pricing acceptability and its impact on the fiscal system.

2003 The development of a methodology for calculating the marginal costs and unification of accounts costs to implement a more efficient transport system. Specifically, delivers 8 reviews in the case of the Spanish study.

INFRAS-IWW 1999-2004 The development of a calculation methodology and the results of total and average social costs.

Quinet 2004 Demonstrates the variability in the estimate of the external costs of transport after an exhaustive review of European studies The development of guidelines for establishing a model of transport costs at the European level, which also includes Switzerland. Specifically, delivers 1 review of the average costs of infrastructure and operation and indicates the variability ranges of European countries.

\begin{tabular}{|c|c|c|c|}
\hline $\begin{array}{l}\text { Implementing Pricing } \\
\text { Reform in Transport } \\
\text { EFFECTIVE Use of } \\
\text { research on pricing } \\
\text { in Europe }\end{array}$ & IMPRINT & 2005 & $\begin{array}{l}\text { The definition of a } \\
\text { costs methodology } \\
\text { for infrastructure } \\
\text { use. Establishes the } \\
\text { consensus between } \\
\text { politicians, transport } \\
\text { operators and experts } \\
\text { on the calculation of a } \\
\text { costs model and the } \\
\text { implementation of a } \\
\text { new pricing system. }\end{array}$ \\
\hline $\begin{array}{l}\text { Use of Revenues from } \\
\text { Transport Pricing }\end{array}$ & REVENUE & 2003-2005 & $\begin{array}{l}\text { An assessment of the } \\
\text { impact of the pricing } \\
\text { policy on the yield } \\
\text { generated and its } \\
\text { effects in terms of } \\
\text { territorial and social } \\
\text { fairness, efficiency } \\
\text { and acceptability. }\end{array}$ \\
\hline
\end{tabular}

Table 1 (continued)

\begin{tabular}{|c|c|c|c|}
\hline Title & $\begin{array}{l}\text { Acronym/ } \\
\text { authors }\end{array}$ & Year & Purpose and content \\
\hline $\begin{array}{l}\text { Generalization } \\
\text { of Research } \\
\text { on Accounts and } \\
\text { Cost Estimation }\end{array}$ & GRACE & 2006 & $\begin{array}{l}\text { Research on } \\
\text { the marginal } \\
\text { costs in transport } \\
\text { case studies. }\end{array}$ \\
\hline $\begin{array}{l}\text { Economic and } \\
\text { Socio-Environmental } \\
\text { Account of overland } \\
\text { passenger transport } \\
\text { in the Autonomous } \\
\text { Community of Madrid } \\
\text { in } 2004\end{array}$ & Monzón et al. & 2007 & $\begin{array}{l}\text { Introduces criteria } \\
\text { for calculating the } \\
\text { socio-environmental } \\
\text { costs of metropolitan } \\
\text { passenger transport. }\end{array}$ \\
\hline
\end{tabular}

Source: Spanish Road PricingModel “Modelo Español de Tarificación de Carreteras”, Monzón, Vassallo, Di Cimmo, and Pérez-Martínez (2008) and this paper.

increase sustainability over time. This situation is not exclusive for Spain and can be transferred to other European countries. This study aims to assess whether there has been a reduction in the external costs of road and rail freight transport in the past couple decades and it to obtain the first estimation values against which future developments may be compared.

This paper has 3 main sections: the methodologies used for assessing the external costs and the subsequent reduction in the externalities of surface freight transport modes in Spain, the fundamental factors that could influence the external costs, and the technological measures that could reduce the external costs even further. Section 1 provides a summary of studies on the estimation of the external costs and offers in depth analyses of the methodology applied in the EU Handbook. The EU methodology is used to first offer an estimation of the external costs of surface freight transport in Spain. The authors then propose an alternative methodology for estimating unit external costs that is tailored to Spanish conditions. The study's sourcing of unit costs, which is based on the EU standard values from the reference EU Handbook on transportation external cost methodology (Maibach et al., 2008), is compared with the authors' individual estimations. Moreover, for both modes of surface transport under review, this study demonstrates the results in absolute economic terms (total costs and cost per externality) and unit efficiency (Euro cents/tonne-kilometre). Section 2 describes the factors that could influence the external costs. Additionally, Section 2 indicates how the relationship between the volume of transported goods and the external costs depends on a series of fundamental factors, such as the handling factor, average length of haul, proportion of journeys with no load, modal share and the intensity of fuel use (and the related intensity of externalities). By analysing the evolution of these fundamental factors in Spain, this study could be applied to the future development of externalities, such as accidents, atmospheric pollution and climate change. Finally, Section 3 reflects on the current and future situations related to the external costs of surface freight transport, and it explores avenues for reducing these costs in the future based on technological measures.

\section{Assessment of external costs}

\subsection{European studies}

European studies concerned with estimating the external costs of transport highlight the importance of internalising the external costs. Thus, these studies begin by defining methodologies that develop models of external costs. All of these studies stress the need to consider the external costs in the taxation system and the infrastructure pricing system (Table 1 ). The studies emphasise that the current tax collection system (particularly the taxes on fuel and 
Table 2

External cost values per tonne-km in Spain, 2005.

\begin{tabular}{|c|c|c|c|c|c|c|}
\hline \multirow{2}{*}{$\begin{array}{l}€ ; \text { cts } 2000 \text { PPP factor } \\
\text { costs/tonne-km }{ }^{\mathrm{a}}\end{array}$} & \multicolumn{3}{|l|}{ Road } & \multicolumn{3}{|l|}{ Rail } \\
\hline & Min. & $\begin{array}{l}\text { Middle } \\
\text { value }\end{array}$ & Max. & Min. & $\begin{array}{l}\text { Middle } \\
\text { value }\end{array}$ & Max. \\
\hline Noise & 0.030 & 0.130 & 0.170 & 0.118 & 0.160 & 0.490 \\
\hline Accidents & 0.020 & 0.230 & 0.299 & 0.020 & 0.023 & 0.086 \\
\hline Air pollution & 0.500 & 0.730 & 1.829 & 0.264 & 0.292 & 0.620 \\
\hline Climate change & 0.051 & 0.190 & 0.342 & 0.024 & 0.087 & 0.159 \\
\hline $\begin{array}{l}\text { Up- and downstream } \\
\text { processes }\end{array}$ & 0.100 & 0.230 & 0.573 & 0.075 & 0.121 & 0.248 \\
\hline Nature and landscape & 0.000 & 0.080 & 0.098 & 0.000 & 0.020 & 0.022 \\
\hline Soil and water pollution & 0.020 & 0.080 & 0.092 & 0.020 & 0.020 & 0.020 \\
\hline Wear and tear & 0.200 & 0.288 & 0.350 & 0.035 & 0.107 & 0.178 \\
\hline Total & 0.921 & 1.958 & 3.753 & 0.556 & 0.830 & 1.823 \\
\hline
\end{tabular}

Note: ${ }^{a}$ the monetary values of the different external costs were proportional to real Spanish per capita Gross Domestic Product (GDP). This adjustment has been made in adapting EU handbook values to Spain according to the purchasing power parity (PPP). PPP described the amount of goods which were bought in Spain compared to the average of the European countries and was expressed relative to $€ 2000$ currency. Source: Maibach et al. (2008) and this paper.

vehicle characteristics) is inefficient and goes against free market competition. In the framework of tax collection, it would be necessary to at least harmonise the fuel tax differentials (Calthrop, de Borger, \& Proost, 2007; EEA, 2006; Johnstone \& Karousakis, 1999; Parry \& Small, 2005). Furthermore, on the subject of infrastructure pricing, a number of problems arise in relation to the recommended manner of establishing tolls, in European directive 2006/38/EC (IMPRINT, 2005). In general, the studies highlight the important role that political components perform in the majority of decisions regarding the implementation of a pricing system. There are territories that are serviced by only one mode of transport or are inefficiently serviced by others. Thus, the impact of pricing on modal transfer is very small (RECORDIT, 2001). In this respect, determining the connections between the pricing system and the external costs originating in the transport modes is complex and, as stressed in the European project REVENUE (2006) requires an understanding of the relationship between the infrastructure, topography and socio-economic characteristics of the territory.

The assessment of the variability range in the average external costs, which has been defined based on the results of projects such as HEATCO (2005) and UNITE (2003), as well as the studies INFRAS (2004) and Quinet (2004), indicates that, in these cost categories (climate change, atmospheric pollution and accidents), it is difficult to make a direct comparison of the values applied in EU countries because of the characteristics of the data available in each country (e.g., inflation rate and currency used). These studies confirm that further research on calculating external costs is required. These studies also concluded that the estimation of these external costs must be based on specific case studies that use a "bottom-up" approach (GRACE, 2006). Likewise, these studies recognised that the acceptability of these costs might pose a problem, as highlighted by the conclusions of the European projects CAPRI (1998), AFFORD (2001) and REVENUE (2006).

\subsection{The EU standard methodology and the first estimation of external costs}

The methodology of the European Union was developed on the basis of the Handbook on estimation of external costs in the transport sector (Maibach et al., 2008). This Handbook reviews European studies published prior to 2008 and is based on the findings of experts and scientists whose work was primarily conducted at the European Union level with the co-operation of Member States (most of which are included in Table 1). The EU
Handbook presents a degree of uncertainty in the calculation of external costs because it relies on values, such as time lost in congestion, lives lost in accidents, premature death due to atmospheric pollution, nuisance due to excessive noise level, and climate change caused by $\mathrm{CO}_{2}$, that scholars and experts on the subject believe are faulty and cannot be used to establish a reference (de Blaeij, Florax,Rietveld, \& Verhoef, 2003; Int Panis, De Nocker, Cornelis, \& Torfs, 2004; Navrud, 2002; Tol, 2005). For example, for the value of one tonne of $\mathrm{CO}_{2}$, the Handbook defines possible scenarios with very significant differences: in 2010, a tonne can cost between 7 and 45 Euros (for the low and high scenarios), and in 2050, a tonne can cost between 20 and 180 Euros.

To arrive at the initial estimate of the surface freight transport externalities in Spain, we have essentially used the methodology provided by the EU Handbook, which makes a calculation of the external marginal cost for trucks and trains per vehicle-km and train- $\mathrm{km}$ in 2005. We have adapted the methodology of the Handbook to the case of interurban road and rail freight transport in Spain, and we have expressed the external costs in Euros per tonne-km. To this end, we have used a loading factor of 7.3 and 283 tonnes/vehicle for trucks and trains respectively (MFO, 2008a; OFE, 2009). Table 2 shows the results of the estimation of the external costs in Spain. The uncertainty issues that are related to the range of variation in the cost estimates have been addressed by including the minimum, maximum and mean values given in the Handbook. As 66\% of railway freight transport in Spain is on electric trains and 34\% relies on diesel trains (RENFE, 2008), the last three columns of Table 2 indicate a weighted average external cost per tonne-km for trains in Spain. We note that, unlike most European countries, congestion on interurban motorways is only a minor problem in Spain.

\subsection{The proposed methodology to estimate the external costs tailored to Spanish conditions}

To assess the external costs generated by road freight transport and their evolution over time, we must first consider the fleet of commercial heavy-duty vehicles in Spain. The technology with which heavy-duty vehicles are fitted, as determined by their initial registration date, has a strong impact on the generation of external costs such as $\mathrm{CO}_{2}$ emissions, the emissions of other pollutants, and accident rates. For example, the different EURO categories entail maximum levels of pollutant emissions that heavy-duty vehicles must observe. Table 3 indicates the emission standards of the different EURO provisions for the main atmospheric pollutants: carbon monoxide $(\mathrm{CO})$, hydrocarbons $(\mathrm{HC})$, nitrous oxides $\left(\mathrm{NO}_{x}\right)$ and particulate matter (PM). We can see how the permitted emissions standards have become increasingly more restrictive over the years (Euro 01990 vs. Euro IV 2005). Having established the emission standards per pollutant and Euro category, we can then weigh up the factors in light of the vehicles registered each year and the Euro category to which they belong. According to the European Commission, the emission standards of commercial vehicles have been reduced by $88 \%$ (between 1982 and 2008), $95 \%$ (1982-2008), 97\% (1982-2008) and 98\% (1992-2008) for CO, HC, $\mathrm{NO}_{x}$ and PM, respectively (Pérez-Martínez \& Monzón de Cáceres, 2008).

The weighted emission factors (Fig. 1a) - the emission standards contained in Table 3 are weighted up by vehicle fleet age distribution - are multiplied by the diesel consumption of heavy-duty vehicles to estimate the emissions per pollutant and year. The weighted emission factors are closely correlated with real world emissions, and they reflect technological changes, partly due to EU regulations, that reduce emissions per energy unit and vehicle kilometre (PérezMartínez, 2012). Despite the attempts of manufacturers to postpone regulations that set stricter standards, emissions of 
Table 3

Emissions legislation and standards for heavy-duty vehicles.

\begin{tabular}{|c|c|c|c|c|c|c|}
\hline Related information & \multicolumn{4}{|c|}{ ECE regulation emission standards in $\mathrm{g} / \mathrm{kWh}(\mathrm{g} / \mathrm{MJ})$} & \multicolumn{2}{|c|}{$\begin{array}{l}\text { EU directive emission standards } \\
\text { in } \mathrm{g} / \mathrm{kWh}(\mathrm{g} / \mathrm{MJ})\end{array}$} \\
\hline & \multicolumn{4}{|l|}{ ECE-R49/00 } & \multicolumn{2}{|c|}{-} \\
\hline In force \& applicable since & \multicolumn{4}{|l|}{ 15-Apr-82 } & \multicolumn{2}{|l|}{-} \\
\hline \multirow[t]{2}{*}{ Standards } & \multicolumn{4}{|c|}{ HC: 3.5 (1.0) CO: 14 (3.9) $\mathrm{NO}_{x}: 18(5.0)$} & \multicolumn{2}{|l|}{-} \\
\hline & \multicolumn{4}{|c|}{ ECE-R49/01 } & \multicolumn{2}{|l|}{ 88/77/EEC } \\
\hline In force since & \multicolumn{4}{|l|}{ 14-May-90 } & \multicolumn{2}{|l|}{ 09-Feb-88 } \\
\hline Applicable since & \multicolumn{4}{|l|}{ 14-May-90 } & \multicolumn{2}{|l|}{$01-$ Oct-90 } \\
\hline \multirow[t]{2}{*}{ Standards } & \multicolumn{4}{|c|}{ "Euro 0" HC: 2.4 (0.7) CO: 11.2 (3.1) $\mathrm{NO}_{x}: 14.4$ (4.0) } & \multicolumn{2}{|c|}{$\begin{array}{l}\text { "Euro 0" HC: } 2.4 \text { (0.7) CO: } 11.2(3.1) \\
\mathrm{NO}_{x}: 14.4(4.0)\end{array}$} \\
\hline & \multicolumn{4}{|l|}{ ECE-R49/02 } & \multicolumn{2}{|c|}{ 91/542/EEC } \\
\hline In force since & \multicolumn{4}{|l|}{ 30-Dec-91 } & \multicolumn{2}{|l|}{25 -oct-91 } \\
\hline Applicable since & \multicolumn{6}{|c|}{ Step A: 1-July-1992 (Euro 1) } \\
\hline \multirow[t]{3}{*}{ Standards } & Step A “Euro 1" & HC: $1.1(0.3)$ & CO: $4.5(1.2)$ & $\mathrm{NO}_{x}: 8.0(2.2)$ & \multicolumn{2}{|c|}{ PM: $0.36(0.1)$} \\
\hline & Step B “Euro 2" & HC: $1.1(0.3)$ & CO: $4.0(1.1)$ & $\mathrm{NO}_{x}: 7.0(1.9)$ & \multicolumn{2}{|c|}{ PM: $0.15(0.04)$} \\
\hline & \multicolumn{4}{|l|}{ ECE-R49/03 } & \multicolumn{2}{|l|}{ 1999/96/EC } \\
\hline In force since & \multicolumn{4}{|l|}{ 27-Dec-01 } & 16-Feb-00 & \\
\hline Applicable since & $\begin{array}{l}\text { Step A: 1-October- } \\
\text { Step B1: 1-October } \\
\text { Step B2: 1-October }\end{array}$ & $\begin{array}{l}(\text { Euro } 3) \\
5 \text { (Euro 4) } \\
8 \text { (Euro 5) }\end{array}$ & & & & \\
\hline Standards ESC ${ }^{\mathrm{a}}$ and $\mathrm{ELR}^{\mathrm{b}}$ : & Valid since & $\mathrm{CO}$ & $\mathrm{HC}$ & $\mathrm{NO}_{x}$ & PM & Opacity $\left(\mathrm{m}^{-1}\right)$ \\
\hline valid for conventional & Oct. 2000 (Euro 3) & $2.1(0.6)$ & $0.66(0.18)$ & $5.0(1.4)$ & $0.10(0.03)$ & 0.8 \\
\hline diesel vehicles with/ & Oct. 2005 (Euro 4) & $1.5(0.4)$ & $0.46(0.13)$ & $3.5(1.0)$ & $0.02(0.01)$ & 0.5 \\
\hline $\begin{array}{l}\text { without Oxicat with/ } \\
\text { without } \mathrm{EGR}^{\mathrm{c}}\end{array}$ & Oct. 2008 (Euro 5) & $1.5(0.4)$ & $0.46(0.13)$ & $2.0(0.6)$ & $0.02(0.01)$ & 0.5 \\
\hline Standards ETC ${ }^{\mathrm{d}}$ : also valid & Valid since & $\mathrm{CO}$ & $\mathrm{NMHC} / \mathrm{CH}_{4}^{\mathrm{f}}$ & $\mathrm{NO}_{x}$ & PM & n.d. \\
\hline for diesel vehicles & Oct. 2000 (Euro 3) & $5.4(1.5)$ & $0.78(0.2) / 1.6(0.4)$ & $5.0(1.4)$ & $0.16(0.04)$ & n.d. \\
\hline with $\mathrm{DeNO}_{x}^{\mathrm{e}}$ and/or PM Filter & Oct. 2005 (Euro 4) & $4.0(1.1)$ & $0.55(0.15) / 1.1(0.3)$ & $3.5(1.0)$ & $0.03(0.01)$ & n.d. \\
\hline & Oct. 2008 (Euro 5) & $2.0(0.6)$ & $0.55(0.15) / 1.0(0.3)$ & $2.0(0.6)$ & $0.03(0.01)$ & n.d. \\
\hline
\end{tabular}

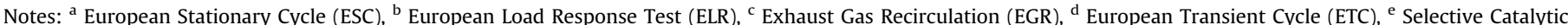
Reduction (SCR) systems, ${ }^{\mathrm{f}} \mathrm{CH}_{4}$ - standards for gas vehicles. 1 Mega-joule (MJ) is equal to $0.2778 \mathrm{~kW}$ hour (kWh). Source: Berg (2003) and this paper.

atmospheric pollutants have fallen as a result of EU regulations and the significant increase in diesel consumption in road freight transport. The weighted emission factors of heavy-duty vehicles have been reduced by 66\% (between 1990 and 2007), 59\%, 54\% and 76\% for CO, $\mathrm{HC}, \mathrm{NO}_{x}$ and PM, respectively. The weighted emission factors used in this paper are higher than the emission factors based on laboratory data and model estimates (Dalmann \& Harley, 2010; Pérez-Martínez, 2012) and similar to the emission rates of real world tunnel experiments (Ban-Weiss et al., 2008; Yanowitz, McCormick, \& Graboski, 2000). Although there are studies which show that the relative decrease in emission factors based on real world data from newer vehicles often is way below the relative decrease in emissions according to the standards (Burgard, Bishop, \& Stedman, 2006), the weighted emission factors used in this paper represent the average age of vehicles in the road freight fleet. The review of relevant literature shows that road vehicle emission predictions have been moving within a factor of 2 of the observed values for $\mathrm{HC}$ and $\mathrm{NO}_{x}$ and within a factor of 3 for $\mathrm{CO}$ and $\mathrm{PM}$, and from overestimation of older vehicles to underestimation of newer vehicles since the late 1990s (Smit, Ntziachristos, \& Boulter, 2010). Including a representative sampling of mean age vehicles could minimize mean prediction errors. In the same way, new vehicles carry new safety systems that have a positive effect on accident rates. However, fleet renewal has not had a clear effect on fuel consumption or $\mathrm{CO}_{2}$ emissions (Fig. 1a). The logic behind the estimates of emissions and intensities has been applied to rail freight, with the exception that there are two fuel technologies, namely diesel and electricity (Fig. 1b). The weighted emission factors of train locomotives have been reduced by $39 \%$ (between 1990 and 2007), 39\%, 33\% and 30\% for CO, HC, $\mathrm{NO}_{x}$ and $\mathrm{PM}$, respectively. Changing from diesel to electric traction has a clear effect on fuel consumption and, consequently, $\mathrm{CO}_{2}$ emissions (-18\%).

The fuel consumption statistics from the road transport sector, which are available in tonnes of diesel (or litres of fuel), have been converted to energy units (Tera-joules, TJ, Peta-joules, PJ and kilowatt-hours, kWh) through the fuel specific net caloric values (NCV). Analogously, the emissions are estimated in millions of tonnes (Mt), kilotonnes (kt) or tonnes of $\mathrm{CO}_{2}$ or pollutant from the energy consumption by using the weighted carbon emission factors (CEF) and the pollutant specific emission factors (PEF). The energy consumption and emissions for the transport mode $i$ (road and rail),
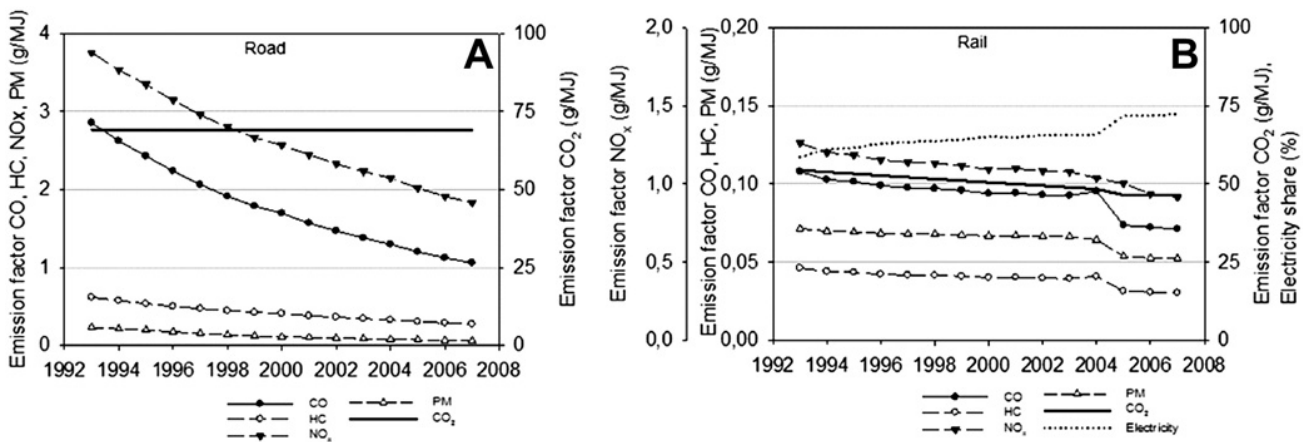

Fig. 1. $\mathrm{CO}_{2}$ and pollutant weighted emission factors for road (a) and rail (b), (1993-2007). 
energy source $j$ (diesel fuel for road and diesel rail, and electricity partially for rail) and pollutant $k$ have been estimated using the following equations:

$$
\begin{aligned}
& E_{i, j}=f_{i, j} \times \mathrm{NCV}_{j} \times D_{i, j} \\
& C_{i, j}=E_{i, j} \times \mathrm{CEF}_{j} \\
& P_{i, j, k}=E_{i, j} \times \mathrm{PEF}_{i, j, k}
\end{aligned}
$$

where $E_{i, j}$ is the interurban energy consumption, expressed in terajoules $\left(\mathrm{TJ}=10^{12} \mathrm{~J}\right), f_{i, j}$ is the fuel consumption, expressed in grams of oil equivalent per vehicle-kilometre (goe/veh-km), $\mathrm{NCV}_{j}$ is the net calorific value of fuel $j$, expressed in mega-joules $\left(\mathrm{MJ}=10^{6} \mathrm{~J}\right.$ ) per gram of oil equivalent (MJ/goe, 0.454 diesel and 0.301 electricity), $D_{i, j}$ is the traffic demand, expressed in millions of vehicle-kms, $C_{i, j}$ are the $\mathrm{CO}_{2}$ emissions, expressed in tonnes of $\mathrm{CO}_{2}$ equivalent $\left(\mathrm{tCO}_{2}\right.$ eq.), $\mathrm{CEF}_{j}$ is the carbon emission factor of fuel $j$, expressed in tonnes of $\mathrm{CO}_{2}$ equivalent per tera-joule ( $\mathrm{tCO}_{2} \mathrm{eq} . / \mathrm{TJ}=\mathrm{g} / \mathrm{MJ}, 69.2$ diesel, 56.2-46.3 electricity), $P_{i, j, k}$ are the emissions of pollutant $k$ (CO, $\mathrm{NO}_{x}, \mathrm{PM}$ and $\mathrm{HC}$ ), expressed in tonnes of pollutant, and $\mathrm{PEF}_{i, j, k}$ is the gas-specific pollutant emission factor, expressed in tonnes of pollutant per tera-joule $(\mathrm{t} / \mathrm{TJ}=\mathrm{g} / \mathrm{MJ})$. Using equations (1)-(3), we have developed an inventory of $\mathrm{CO}_{2}$ emissions and pollutants $(\mathrm{CO}$, $\mathrm{HC}, \mathrm{NO}_{x}, \mathrm{PM}$ ) for the interurban freight road and rail transport in Spain for the period 1993-2007. To address the uncertainties by an appropriate allocation of activity and fuel data across different types of vehicles (Kühlwein \& Friedrich, 2005; Saari, Lettenmeier, Pusenius, \& Hakkarainen, 2007), and to be sure that estimates are consistent with fuel sales, we cross-checked the total emissions predicted by equations (1) and (2) against the total national fuel sales published by the Spanish Government (MFO, 2008b).

Once a global analysis concerning the dimension of the problem was made from the energy and emissions standpoint, we next analysed the intensity and efficiency of energy because the absolute figures vary to a considerable extent with the increase in the units transported by each mode of transport. We accomplished this task by merging the data for energy consumption and emissions with the data for transport activity. The result of this merge expresses intensity (the consumption of resources) and efficiency (energy and/ or environmental). Energy intensity is determined by two factors: the energy required to move the vehicle and the use of the vehicle's capacity (Pérez-Martínez \& Sorba, 2010). The energy required to move the vehicle is determined by the fuel consumption, transport conditions (traffic and geography) and the vehicle's characteristics (model and size). The use of the vehicle's capacity depends on the levels of occupancy and load for each individual vehicle, the relative use of each type of vehicle, and the distribution of the different types of vehicles within the fleet of vehicles as a whole (Leonardi \& Baumgartner, 2004). Additionally, the concept of environmental intensity must be defined for $\mathrm{CO}_{2}$ and each of the air pollutants, as well as for noise and accidents (Saricks, Vyas, Stodolsky, \& Maples, 2003). The energy and environmental intensities are measured in terms of energy consumption, emissions of $\mathrm{CO}_{2}$ and each pollutant per tonne kilometre using the following equations:

$$
\begin{aligned}
& E_{i, j}^{\prime}=E_{i, j} / t_{i, j} \\
& C_{i, j}^{\prime}=C_{i, j} / t_{i, j} \\
& P_{i, j, k}^{\prime}=P_{i, j, k} / t_{i, j}
\end{aligned}
$$

where $E_{i, j}^{\prime}$ is the energy intensity, expressed in MJ per tonnekilometre $(\mathrm{MJ} / \mathrm{t}-\mathrm{km}), C_{i, j}^{\prime}$ is the $\mathrm{CO}_{2}$ emissions intensity, expressed in grams of $\mathrm{CO}_{2}$ equivalent per tonne-kilometre $\left(\mathrm{gCO}_{2}\right.$ eq./t-km), $P_{i, j, k}$ is the $k$ pollutant emissions intensity, expressed in grams of pollutant per tonne-kilometre $(\mathrm{g} / \mathrm{t}-\mathrm{km}), t_{i, j}$ is the freight transport performance, expressed in millions of tonne-km, and $E_{i, j}, C_{i, j}$, and $P_{i, j, k}$ are derived from equations (1)-(3). Similar to the energy and emissions intensities, the accident intensity is estimated using the following equation:

$A_{i}=\left(f a_{i}+\sin _{i}+\operatorname{hin}_{i}\right) / t_{i}$

where $A_{i}$ is the accident intensity of transport mode $i$, expressed as the number of cases (fatalities and injuries) per million tonnekilometres (cases $\left./ 10^{6} \mathrm{t}-\mathrm{km}\right), f a_{i}, \sin _{i}$ and $\operatorname{hin}_{i}$ are the number of fatalities, slight injuries and heavy injuries related to freight transport operations, respectively, and $t_{i}$ is the freight transport performance (in millions of tonne kilometres). Safety related external costs are relatively low compared to polluting emissions and $\mathrm{CO}_{2}$ and this is why we paid less attention to this type of costs.

Finally, the external costs are estimated for road and rail freight transport by converting the emissions and accident intensities into monetary values using the following equation:

$$
\begin{aligned}
E C_{i}= & \left.10^{-4} \times c_{\mathrm{CO}_{2}} \times C_{i}^{\prime}+\sum_{k=1}^{4} c_{p k} \times P_{i, k}^{\prime}\right)+10^{2} \times\left(c_{f a} \times f a_{i}\right. \\
& \left.+c_{\sin } \times \sin _{i}+c_{\text {hin }} \times \operatorname{hin}_{i}\right) / t_{i}
\end{aligned}
$$

where $E C_{i}$ is the external cost of transport mode $i$, expressed in Euro cents per tonne-kilometre ( $€ \mathrm{cts} / \mathrm{t}-\mathrm{km}), C_{\mathrm{CO}_{2}}$ is the cost per tonne of $\mathrm{CO}_{2}(25 €), c_{p k}$ is the cost per tonne of pollutant $k(0 € / \mathrm{tCO}, 400$ $€ / \mathrm{tHC}, 2600 € / \mathrm{tNO}_{x}$ and $\left.16,500 € / \mathrm{tPM}\right), c_{f a}$ is the cost of a fatality case (1.12 $\mathrm{M} € /$ case $), c_{\text {sin }}$ is the cost of a slight injury case $(0.01 \mathrm{M} € /$ case), $c_{\text {hin }}$ is the cost of a heavy severe injury case $(0.14 \mathrm{M} € /$ case), and $C_{i}^{\prime}, P_{i, k}^{\prime}, f a_{i}, \sin _{i}$ and $h i n_{i}$ are derived from equations (5)-(7). The monetisation of emissions and accidents was performed based on the values that other European studies gave to a tonne of $\mathrm{CO}_{2}, \mathrm{CO}$, $\mathrm{HC}, \mathrm{NO}_{x}$ and $\mathrm{PM}$ and to the value of a person killed or injured in a traffic accident (Maibach et al., 2008; INFRAS-IWW, 2004; UNITE, 2003). Equation (8) takes into account the monetary prices ( $€ 2000$, constant prices) of associated $\mathrm{CO}_{2}$ and pollutant emissions and transport accidents. The monetary values of the different external costs of the transport modes were proportional to the Spanish per capita Gross Domestic Product (GDP/capita) and were expressed in $€$; cts 2000 purchasing power parity (PPP) factor costs per year and per tonne-kilometre ( $€$; cts 2000 PPP factor costs/t-km). This adjustment has been made in adapting EU handbook values to Spain according to the PPP and considering the elasticity of the $\mathrm{GDP} /$ capita growth equal to 1.0 (Maibach et al., 2008). The use of monetary emission and accident prices is proposed in this paper to connect energy, emission, environmental and accident aspects (time series analysis in a cost uniform basis). The monetary criteria have the advantage of evaluating these four aspects on a uniform basis, although we know that monetary estimation is of course a critical point. $\mathrm{CO}_{2}$ emission price estimation is not an easy task due to critical aspects such as the market prices of energy. The energy prices (closely connected to oil prices), and subsequent climate change prices, are not stable over time and therefore their forecasting is not easy. Assigning prices to pollutant specific emissions is also a complex task, due to the subjective and discretional character of such an assignment. These prices depend on the impact on human health, material damage and crop losses (INFRAS-IWW, 2004; UNITE, 2003). Prices of the tonnes of pollutants have been adopted in the present paper taking into account 
population densities, meteorological conditions and traffic patterns outside of built up areas (Torchio \& Santarelli, 2010).

\section{Results for the external costs of freight surface transport in Spain}

\subsection{Intensity of the external costs and trends}

Based on the consumption associated with $\mathrm{CO}_{2}$ emissions, the emissions of atmospheric pollutants and the data available on transport activity, we calculated the intensities (the inverse of the efficiency) expressed as grams per tonne kilometre (Fig. 2). From 1993 to 2007, the intensity of the pollutants of road freight fell from 11.64 to $3.63 \mathrm{~g}$ per tonne kilometre and from 8.85 to 2.10 , from 1.91 to 0.54 and from 0.71 to 0.12 , for $\mathrm{NO}_{x}, \mathrm{CO}, \mathrm{HC}$ and $\mathrm{PM}$, respectively. We see an improvement in efficiency during the period reviewed. For the four pollutants, there were significant reductions of the grams per tonne kilometre of approximately $70 \%$. The intensity of the $\mathrm{CO}_{2}$ emissions of road freight fell from 214.7 to 137.7 (36\%). Our findings indicate that the intensities fell at a slower rate for rail freight than they for road freight transport (Fig. 2).

Table 4 indicates the current emission factors of the four main atmospheric pollutants ( $\mathrm{CO}, \mathrm{HC}, \mathrm{NO}_{x}$ and $\mathrm{PM}$ ) for both commercial road vehicles and locomotives. Given the distribution of energy consumption per type of fuel in the sector, the emission factors of diesel locomotives are applicable in 34\% of cases (RENFE, 2008). Additionally, the emission factors of electric locomotives are applicable in $66 \%$ of cases. On the road, only one fuel technology is considered (diesel). Our findings indicate that, in terms of $\mathrm{CO}$ and $\mathrm{HC}$, the emissions per unit of energy consumed on the road are higher than the emissions consumed by rail. However, the PM emissions factor is lower for road transport than for rail. In the case of electric technology, the $\mathrm{NO}_{x}$ emissions factor is lower for rail transport than for road. The carbon and pollutant contents of energy delivered as electricity depends on the mix of fuels used for generation, in grams of oil equivalent (goe) and pollutant (Hernández-Martínez, 2006). In 2007, the annual balance of Spain's electric energy exploitation was: hydro (4.8\%), nuclear (30.3\%), national coal (28.7\%), imported coal (7.0\%), natural gas (17.7\%), oil (1.4\%), and sun, wind and thermal (10.2\%). Coal is the most carbon and pollutant intensive, followed by oil and natural gas. For nuclear energy and renewable energy sources (such as biomass, hydro, solar, wind, and geothermal), a net carbon emission of zero is assumed (Schipper, Scholl, \& Price, 1997). Although electricity makes up only a small share of the final energy used for freight transportation in Spain (around0.8\%), the carbon and pollutant emissions from power generation are counted (MFO, 2008b). The following fuel conversion coefficients for electricity production were considered (average values in 2007): 184.4 goe per kilowatt hour (goe/kWh) and51.2 g of $\mathrm{CO}_{2}$ per mega-joule $\left(\mathrm{gCO}_{2} / \mathrm{MJ}\right)$.
Table 4

Emission factors of heavy-duty road vehicles and trains (2005).

\begin{tabular}{|c|c|c|c|}
\hline \multirow[t]{2}{*}{$\mathrm{G} / \mathrm{MJ}$} & Road (diesel 100\%) & Diesel train (34\%) & Electric train (66\%) \\
\hline & EURO IV (2005) & 2005 & 2005 \\
\hline $\mathrm{CO}$ & 0.42 & 0.24 & 0.02 \\
\hline $\mathrm{HC}$ & 0.13 & 0.10 & 0.01 \\
\hline $\mathrm{NO}_{x}$ & 0.56 & 2.79 & 0.18 \\
\hline $\mathrm{PM}$ & 0.01 & 0.11 & 0.04 \\
\hline
\end{tabular}

Source: Handbook of Environmental Chemistry, Gruden (2003) and Renfe's Environmental Yearbook, Renfe (2008).

Fig. 3a and $\mathrm{b}$ indicate the intensity of the external costs generated by road and rail freight transport in Spain and were prepared using the estimates of the above-mentioned emissions plus the number of accidents involving road and rail freight transport (the number of people injured or killed). Related to the tonnekilometres transported, these costs are expressed in Euro cents for the year 2000. For road transport, the intensity of the external costs for accidents, pollution and climate change was reduced from 3.97 Euro cents per tonne kilometre in 1993 to 2.24 Euro cents per tonne kilometre in 2007 (44\%). Oppositely, the intensity of the external costs for rail was slightly increased from 0.25 Euro cents per tonne kilometre to 0.27 Euro cents per tonne kilometre (12\%). In Fig. $3 a$ and $b$ the external cost estimates have been changed over time in accordance with growth in Spanish GDP per capita, contrarily to the results shown in Fig. 3c and d (constant values). Fig. 2a shows that for road transport grams of the 4non greenhouse gas pollutants per tonne $\mathrm{km}$ fell by $70 \%$, similarly to the external cost per tonne shown in Fig. 3c. However, the estimate of Fig. 3a is smaller compared with the estimate of Fig. 3c by growth in monetary values over time as per capita GDP rose (51\% vs. $73 \%$ ). The differences between the figure results, both at constant values and with monetary values varying over time, clarify what is the physical improvement (Fig. 2 and Fig. $3 c$ and d) and how far this is offset by rising monetary values (Fig. 3a and b). For road transport the reduction of the intensity of $\mathrm{CO}_{2}$ emissions is correlated to the efficiency increment of diesel engines, a $30 \%$ reduction in energy consumption and $\mathrm{CO}_{2}$ emissions, and the physical improvement is totally offset by the growth in the GDP per capita ( $-36 \%$ vs. $15 \%$ ). For rail transport the reduction of the intensity of pollutant emissions is correlated to the reduction in diesel consumption and the increment in the proportion of trains using electricity (due to the electrification of new lines), and also the physical improvement is fully offset ( $-42 \%$ vs. $4 \%$ ). For road freight transport in Spain, the European studies reviewed in Table 2 underestimate the external costs related to climate change. However, the European studies overestimate the external costs related to the air pollution caused by rail freight transport in Spain. The other external costs are within the range of the external costs values per tonne kilometre in Table 2.

Fig. 3a and $b$ also highlight the external cost estimates of accidents, air pollution and climate change for road and rail freight
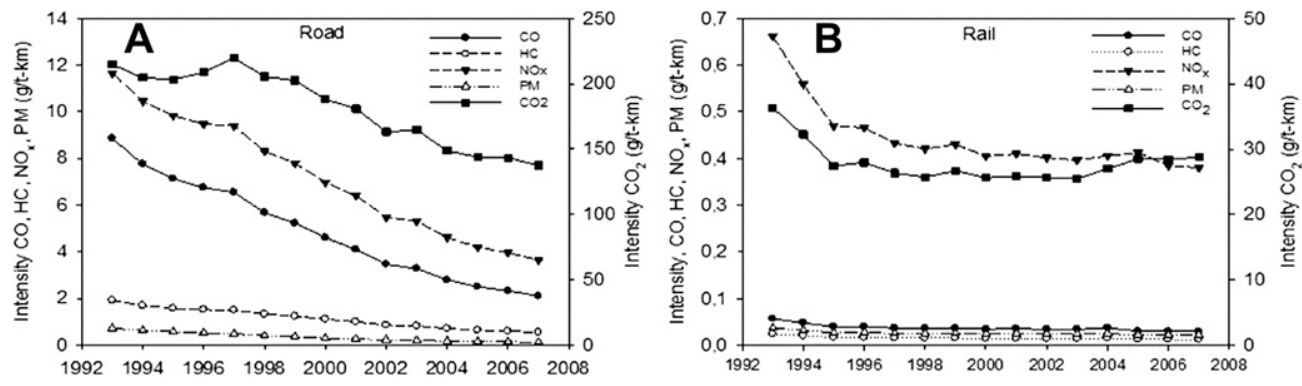

Fig. 2. The intensity of atmospheric pollution by freight transport in Spain: $\mathrm{CO}, \mathrm{HC}, \mathrm{NO}_{x}$ and $\mathrm{PM}$, as well as $\mathrm{CO}_{2}$ emissions, for road (a) and rail (b), (1993-2007). 

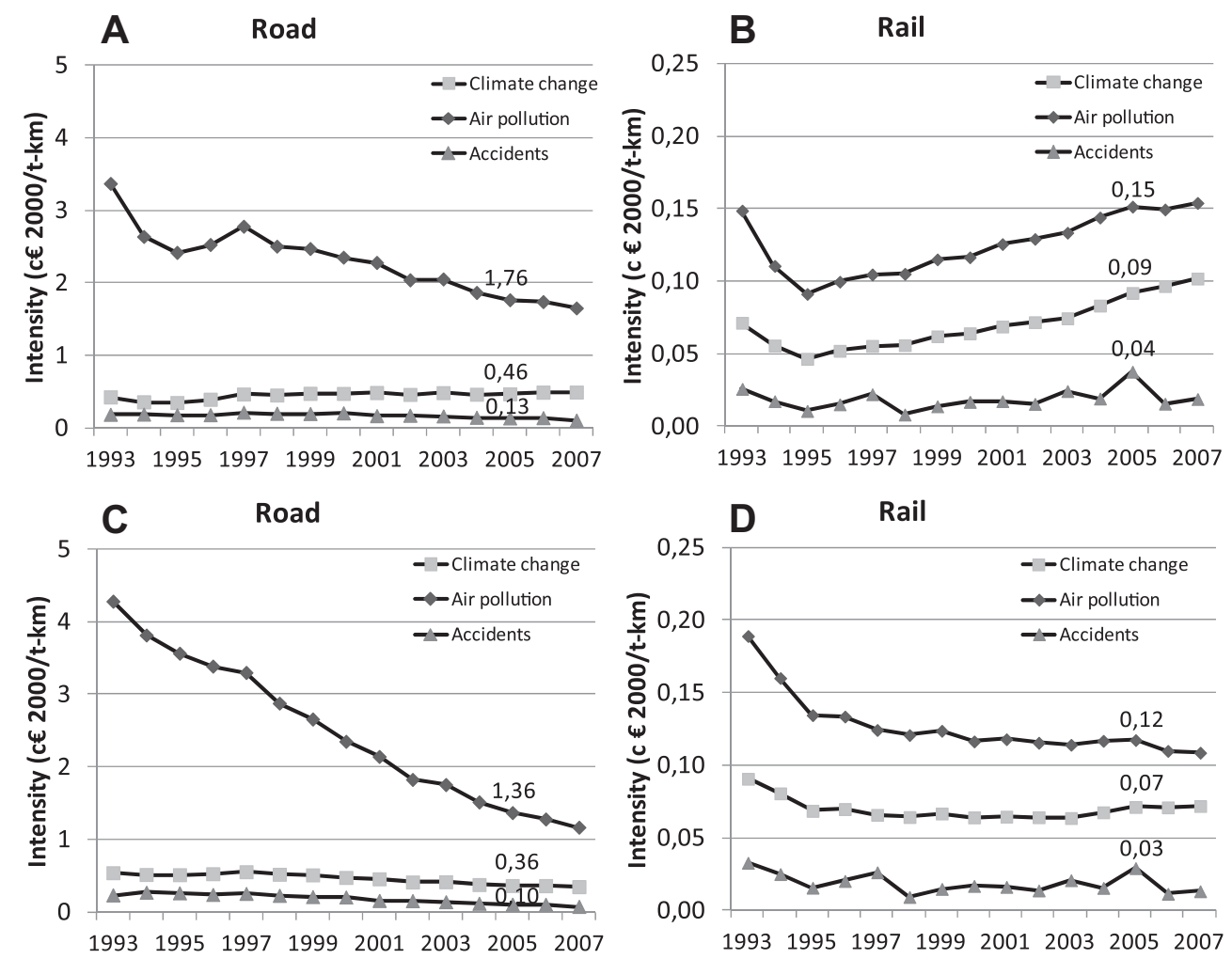

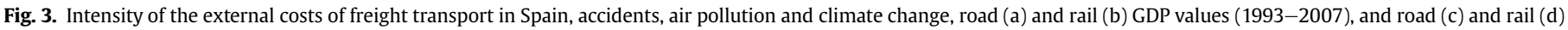
constant values (1993-2007).

operating between urban areas in Spain in the year 2005. The total external cost for road freight is 2.35 cents per tonne-kilometre (5.6\% accidents, $74.7 \%$ air pollution and $19.7 \%$ climate change). For rail freight, the per-tonne-kilometre external cost totals 0.24cents (13.4\% accidents, $53.9 \%$ air pollution and $32.7 \%$ climate change). It is important to note the highly different nature in which these two modes operate. On a per-tonne-kilometre basis, road freight generates over eight times the external cost of rail freight. The growing social awareness in recent years of the need to reduce external costs has meant that initial measures have been adopted to internalise the external costs, through taxes, large investments in vehicle technology and the management of transport supply and demand policies. In any case, the external costs of interurban freight transportation in Spain are considerable (4042 million Euros in 2005) compared to the private costs that are the basis for freight rates (Vassallo, Solís, Pérez-Martínez, \& Pérez de Villar, 2009). The external costs are equivalent to $0.6 \%$ of GDP (INE, 2008). The value of the external costs is nonetheless far lower than the value of the freight transport sector's contribution to the GDP (4.68\% in 2005). Depending on the vehicle type, activity and commodity, trucks have operating costs close to 13.7 cent per tonne-kilometre (MFO, 2007). Using the values from our analysis, the external costs represent approximately $17 \%$ of the total operational costs, and the costs of freight shipments would increase by this rate if the external costs related to accidents, air pollution and climate change were included in the costs faced by truck freight providers. This percentage is similar to the values found in the literature (Forkenbrock, 1999; Janic, 2007, 2008). However, in relation to fiscal taxes, which equalled 4403 million Euros in 2005, these external costs were fully internalised by road freight prices (Vassallo et al.,

Table 5

External cost of freight accidents for both road and rail (2005).

\begin{tabular}{|c|c|c|c|c|c|}
\hline Accident type & Cost per person ${ }^{\mathrm{a}}(€ 2000)$ & Number of people ${ }^{b}$ & $\begin{array}{l}\text { Amount } \\
(\text { million } €)\end{array}$ & $\begin{array}{l}\text { Tonne-kilometres }{ }^{c} \\
\text { (millions) }\end{array}$ & $\begin{array}{l}\text { Cost per tonne-kilometre } \\
\text { (€cts2000) }\end{array}$ \\
\hline \multicolumn{6}{|l|}{ Road } \\
\hline Fatality & $1,122,000$ & 138 & 154.8 & - & 0.09 \\
\hline Severe injury & 138,900 & 480 & 66.7 & - & 0.03 \\
\hline Slight injury & 10,500 & 1456 & 15.3 & - & 0.01 \\
\hline Total & - & 2074 & 236.8 & 233,219 & 0.13 \\
\hline \multicolumn{6}{|l|}{ Rail } \\
\hline Fatality & $1,122,000$ & 3 & 3.4 & - & 0.04 \\
\hline Severe injury & 138,900 & 0 & 0.0 & - & 0.00 \\
\hline Slight injury & 10,500 & 1 & 0.0 & - & 0.00 \\
\hline Total & - & 4 & 3.4 & 11,641 & 0.04 \\
\hline
\end{tabular}

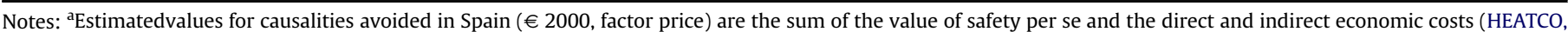

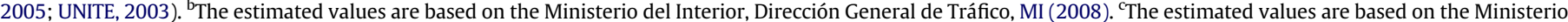

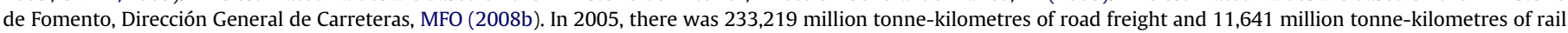
freight transport performance in Spain. 
Table 6

External cost of air pollution for both road and rail (2005).

\begin{tabular}{|c|c|c|c|c|c|}
\hline Pollutant & $\begin{array}{l}\text { Cost per } \\
\text { tonne }^{\mathrm{a}} \\
(€ 2000)\end{array}$ & $\begin{array}{l}\text { Emission }^{\mathrm{b}} \\
\text { (tonnes) }\end{array}$ & $\begin{array}{l}\text { Tonne-kilometres }{ }^{\mathrm{c}} \\
\text { (million) }\end{array}$ & $\begin{array}{l}\text { Emission rate } \\
\text { (g/tonne-kilometre) }\end{array}$ & $\begin{array}{l}\text { Cost per } \\
\text { tonne-kilometre (€cts2000) }\end{array}$ \\
\hline \multicolumn{6}{|l|}{ Road } \\
\hline $\mathrm{CO}$ & 0 & 582,672 & - & 2.50 & 0.000 \\
\hline $\mathrm{HC}$ & 400 & 148,056 & - & 0.63 & 0.032 \\
\hline $\mathrm{NO}_{x}$ & 2600 & 978,673 & - & 4.20 & 1.407 \\
\hline $\mathrm{PM}$ & 16,500 & 35,014 & - & 0.15 & 0.320 \\
\hline Total & & $1,744,414$ & 233,219 & 7.48 & 1.759 \\
\hline \multicolumn{6}{|l|}{ Rail } \\
\hline $\mathrm{CO}$ & 0 & 353 & - & 0.03 & 0.000 \\
\hline $\mathrm{HC}$ & 400 & 151 & - & 0.01 & 0.001 \\
\hline $\mathrm{NO}_{x}$ & 2600 & 4806 & - & 0.41 & 0.138 \\
\hline PM & 16,500 & 257 & - & 0.02 & 0.012 \\
\hline Total & & 5567 & 11,641 & 0.48 & 0.151 \\
\hline
\end{tabular}

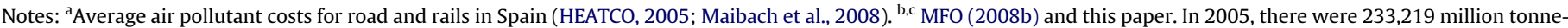
kilometres of road freight and 11,641 million tonne-kilometres of rail freight transport performance.

2009). In Spain, the public sector income generated by taxes and financial mechanisms compensated for these external costs.

Road freight transport in Spain was estimated to have produced $3.97 € \mathrm{cts} / \mathrm{t}-\mathrm{km}$ of external costs in 1993. That figure decreased to $2.24 € \mathrm{cts} / \mathrm{t}-\mathrm{km}$ in 2007 . This reduction (44\%) is similar to the decreased rate of the intensity of road freight pollutant emissions and accidents, which decreased from 3.36 to $0.18 € \mathrm{cts} / \mathrm{t}-\mathrm{km}$ in 1993 to 1.65 and $0.10 € \mathrm{cts} / \mathrm{t}-\mathrm{km}$ in 2007 , respectively. The decrease in the intensities has primarily been attributed to the technological advances in vehicles and related pollutant emission factors. The intensity of road freight $\mathrm{CO}_{2}$ emissions increased (16\%). The external costs of rail freight transport increase between 1993 and 2007 (12\%). Therefore, the intensity of freight rail pollutant and $\mathrm{CO}_{2}$ emissions increased from 0.14 to $0.15 € \mathrm{cts} / \mathrm{t}-\mathrm{km}$ (4\%) and from 0.07 to 0.10 (43\%). However, the intensity of freight rail accidents experienced a downward trend. The external costs of road freight transport during the period 1993-2007 are decreasing over time, oppositely to the external costs of rail transport. Input parameters, such as the cost of one tonne of $\mathrm{NO}_{x}, \mathrm{PM}, \mathrm{CO}_{2}$, and the transport performance, have a significant effect on external costs estimates for both road and rail freight transport.

\subsection{External costs of road and rail freight}

In Table 5, the accidents involving road and rail freight, expressed as the number of fatal and personal injuries, are multiplied by the appropriate per-event cost (after subtraction of the amount of compensation already paid by the particular mode, updated to the value of the Euro in the year 2000) and divided by the number of tonne-kilometres, to estimate the per-tonnekilometre external cost for each mode. The per-event costs were equal for the road and rail freight. Accidents involving freight trains fall into five categories: collision, derailment, level-crossing accidents, and accidents to people caused by rolling stock motion and fires. The most frequent types of fatal rail accidents are levelcrossing accidents and accidents to people caused by rolling stock motion. Most injuries involve railroad employees on duty (ADIF, 2009). Freight transport in Spain contributes only 6\% of the victims of total rail traffic, in contrast to the $16 \%$ average value for
Europe (UIC, 2009). In total, there were 3 fatalities and 1 slight injury casualty in 2005, which accounted for 3.4 million Euros. These figures are small compared with the 138 fatalities and 480 severe injuries caused by freight road in Spain (236.8 million Euros). The accident costs per tonne-km obtained in this paper (0.13Eurocents road and 0.04rail) are within the ranges of the values indicated in the study by the European Commission and in Table 2 (0.02-0.30 €cts/t-km for road and $0.02-0.09$ for rail).

Together with the estimates of emission rates per tonnekilometre of cargo and the estimated emission cost per tonnekilometre for freight road and rail in 2005, Table 6 depicts the costs per tonne for the four main types of air pollutants. On a tonnekilometre basis, the total costs of the air pollution from road freight are higher than those from rail ( 1.76 vs. $0.15 € \mathrm{cts})$. From this result, it is fair to conclude that the external costs of air pollution generated by freight rail operating in interurban areas in Spain are small. A higher estimate of this cost was made by the European Commission (Table 2), which estimated the air pollution costs associated with shipping one tonne-kilometre to be $0.29 €$ cts. The differences between these estimates are due to the type of train considered (66\% of train operations in Spain are conducted by electric trains), the trailing tonnage (approximately 281 tonnes per train) and the speed used in the analysis (approximately $54 \mathrm{~km}$ per hour). For instance, the per tonne-kilometre pollution cost will be higher in mountainous terrain, where there are more diesel locomotives, or when freight trains are transporting fewer tonnes per kilometre of travel.

Table 7 indicates the amount of $\mathrm{CO}_{2}$ released per tonnekilometre, which is related to the energy efficiency of the freight mode and to the source of energy used. According to the Spanish electricity mix in 2005, $1 \mathrm{~L}$ of diesel fuel releases $2660 \mathrm{~g}$ of $\mathrm{CO}_{2}$ (69.2 $\mathrm{gCO}_{2}$ eq./MJ), and $1 \mathrm{~kW}$-hour of electricity releases $184 \mathrm{~g}$ of $\mathrm{CO}_{2}$ (Pérez-Martínez, 2009). Researchers and policy makers have not yet reached a consensus regarding the cost to society of releasing $\mathrm{CO}_{2}$ into the atmosphere. Monzón et al. (2007) reviewed different European studies regarding the external costs of $\mathrm{CO}_{2}$, and they suggest costs in the range of 5-38 Euros per tonne of $\mathrm{CO}_{2}$ emitted. The $\mathrm{CO}_{2}$ emissions per tonne-kilometre for road and rail freight are estimated to be 144 and $28.5 \mathrm{~g}$, which equals an external

Table 7

External cost of climate change for both road and rail (2005).

\begin{tabular}{|c|c|c|c|c|c|}
\hline Mode & Cost per tonne ${ }^{\mathrm{a}}(€ 2000)$ & Emission $^{\mathrm{b}}$ (tonnes) & Tonne-kilometres $^{\mathrm{c}}$ (million) & Emission rate (g/tonne-kilometre) & Cost per tonne-kilometre ( $€$ cts2000) \\
\hline Road & 25 & 33,586 & 233,219 & 144.01 & 0.46 \\
\hline Rail & 25 & 332 & 11,641 & 28.51 & 0.09 \\
\hline
\end{tabular}

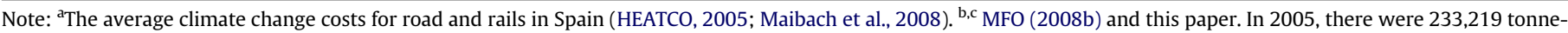
kilometres of road freight and 11,641tonne-kilometres of rail freight. 
cost of 0.46and 0.09 Euro cents, respectively. The European Commission (Table 2) offers a lower estimate of this cost for road freight transport. Because of a more conservative price of the tonne of $\mathrm{CO}_{2}$, the European Commission indicates that the climate change cost associated with shipping one tonne-kilometre is $0.19 €$ cts.

\section{Fundamental factors that influence external costs}

There are fundamental factors that influence the volume of freight transport performance and the resultant externalities
(Fig. 4). These factors represent the links between freight transport and economic activities and relate the amount of freight produced/ consumed to the externalities produced during transport operations (each factor converts one product value into another). For example, the handling factor (the number of links in the supply chain) converts the weight of the freight produced/consumed into transported tonnes (Browne, Allen, \& Rizet, 2006; Browne, Rizet, Anderson, Allen, \& Keïta, 2005). As the freight produced/ consumed goes through the supply chain, it is loaded onto vehicles several times. The handling factor can be defined as the volume of

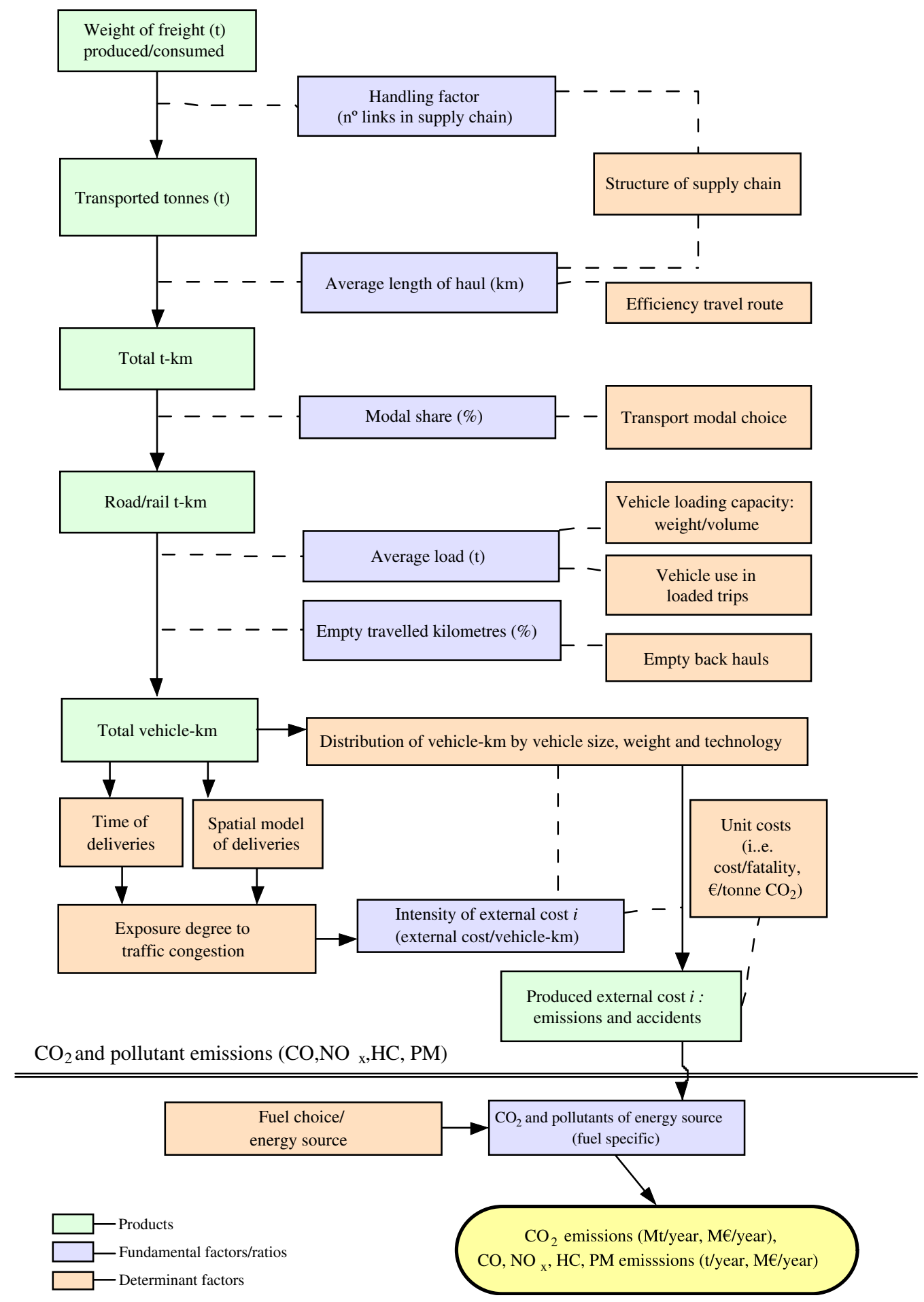

Fig. 4. Framework to analyse the opportunities to reduce the external costs of surface freight transport: $\mathrm{CO}_{2}$, pollutant emissions and accidents. 
freight generated per tonne of product produced/consumed. The average length of haul, which is an estimate of the average distance of each link in the supply chain, converts the tonnes transported into tonne-kilometres. The handling factor and the average length of haul are influenced by the structure of the supply chain, and they determine the transport intensity in the economy (McKinnon, 2007). The average length of haul is also determined by the efficiency in the choice of travel route. The modal distribution indicates the proportion of tonne-kilometres transported by each mode of transport and depends on the choice of the mode of transport (Schipper et al., 1997). The number of trucks/trains required to transport the tonne-kilometres is determined by the average load of the trips and the proportion of kilometres travelled with no load. In turn, the average load of the trips depends on the capacity of the vehicles (in weight and volume) and on the use of the vehicle in journeys with a load (Leonardi \& Baumgartner, 2004). The proportion of kilometres travelled with no load influences the occupancy rate (the average load factor) of the return trips. The externalities that are produced (i.e., $\mathrm{CO}_{2}$ emissions and air pollution) will be subject to the intensity/efficiency levels (i.e., fuel and vehicle efficiencies) with which the vehicles operate. These operation intensities/efficiencies will be established in part by the traffic conditions at specific hours of the day on specific roads (Haney, O'Mahony, \& Gibbons, 2005) and factors such as the vehicle technology and size. Produced external costs, emissions and accidents, depend on unit costs (i.e., $€$ per tonne of $\mathrm{NO}_{x}$ and $€$ per fatality case). Finally, total emissions of $\mathrm{CO}_{2}$ and pollutants (in million tonnes per year and million $€$ per year) depend on the fuel choice (diesel or electricity) and are function of the $\mathrm{CO}_{2}$ and pollutant content of the energy source: sum of the emissions in the "tank to wheel" and the emissions in the "well to tank" processes. For instance, the $\mathrm{CO}_{2}$ content for electricity consumed on the Spanish railway, according to the national energy mix, was $246.8 \mathrm{gCO}_{2} / \mathrm{kWh}$ (2007). The $\mathrm{CO}_{2}$ content for diesel fuel consumed on the roads and railways was $262.2 \mathrm{gCO}_{2} / \mathrm{kWh}$ (Pérez-Martínez, 2010). It is obtained by dividing the carbon content of diesel $\left(2660 \mathrm{~g} \mathrm{CO}_{2} / \mathrm{l}\right)$ by the fuel energy content ( $38.3 \mathrm{MJ} / \mathrm{l}$ and $3.6 \mathrm{MJ} / \mathrm{kWh}$ ), emissions in the "tank to wheel" process, and adding the emissions in the "well to tank" process (14.6 $\mathrm{g}$ of fuel per kWh of final energy).
The fundamental factors thus far described may vary depending on the industrial sector considered (Pimentel et al., 2004), the nature of the product distribution operation (Ang-Olson \& Schroeer, 2002; Browne et al., 2005), the type of freight transported (Vanek \& Campbell, 1999; Vanek \& Morlok, 2000) and the type of vehicle used (Saari et al., 2007; Saricks et al., 2003). This study analyses the data for the freight transport sector as a whole, which includes both road and rail. Fig. 5 depicts the evolution of some of the factors described above in Spain from 2002 to 2007: the length of haul (a), modal distribution (b), average load (c), and the energy intensity levels (the inverse of the efficiency levels) (d). During this period, the road length of haul remained constant, and the rail length of haul decreased by almost $20 \mathrm{~km}$. There was a shift towards more road freight, which translated into rail transport demand losses. The average load, both for rail and road, did not vary. The energy intensity levels of rail freight transport, expressed in terms of mega joules of energy per vehicle kilometre, increased from 105 MJ per train kilometre to 118. However, the energy intensity of road freight transport decreased by $16 \%$. Small changes in the transport specific length of haul, modal distribution and average load can be expected in the next years, having relatively small influence on the production of external costs. Further improvement on the energy intensity levels are expected, both for road and rail modes, but at a lower rate than in the recent years.

In determining the $\mathrm{CO}_{2}$ pollutant emissions and the global calculation of the climate change and pollution externalities, we need to shift from a focus on the energy used to the $\mathrm{CO}_{2}$ and pollutant emission factors of the considered vehicle and the source of energy (equations (2) and (3)). These emission factors depend on the choice of fuel employed in the transport activity, on the source of energy and on the vehicle used (Orasch \& Wirl, 1997; Van Wee, Janse, \& Van Den Brink, 2005). However, a life cycle analysis of the $\mathrm{CO}_{2}$ emissions per litre of the different types of fuels may vary significantly depending on the nature and location of the raw material, the fuel production efficiency and the distribution systems (Kaul \& Edinger, 2004). According to the framework shown in Fig. 4, a combination of clean vehicles with a high ratio of net tons carried with respect to tare, using cleaner fuels from closer energy sources, leads to lower external cost production per
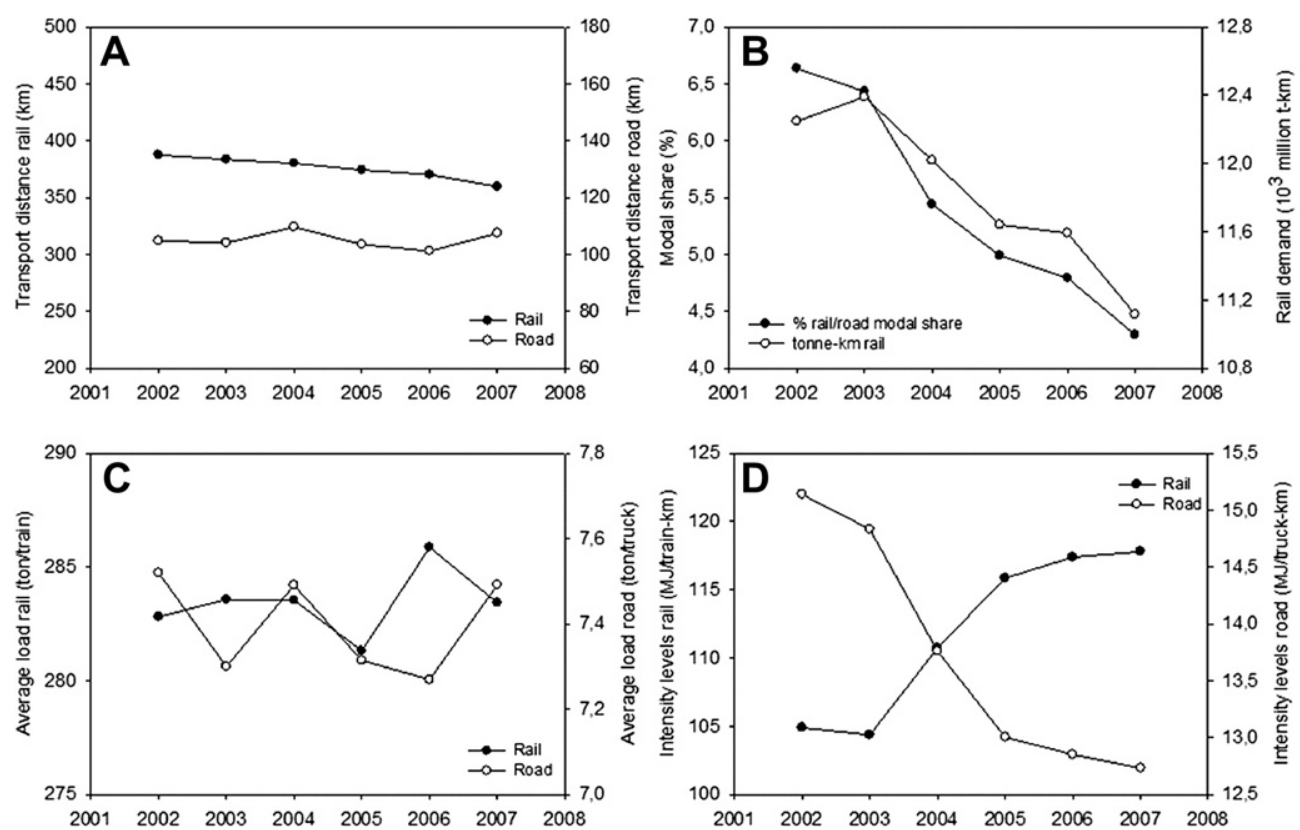

Fig. 5. Fundamental factors in rail and road freight: length of haul (a), modal share and rail tonne-km (b), average load (c) and intensity levels (d), $2002-2007$. 
equivalent transport unit. This combination will be important to reduce energy and environmental intensity levels and subsequent external costs in the next years.

The organisation and management type are fundamental factors. Although they are considerably influenced by economic, productive and territorial conditions, these factors directly depend on the transport sector. The average length of haul can be reduced by reorganising the production and distribution systems, supplying local products and finding short routes between pick-up and delivery points (Baumgartner, Leonardi, \& Krusch, 2008). Whenever possible, production can be decentralised and linked to the consumption centre, which would reduce the average length of haul and the handling factor at the cost of increased transport costs (McKinnon, 2008). Finally, technological advances and measures help minimise the externalities by improving the environmental efficiency, which is attained because of large economic investments made by vehicle and fuel manufacturers (Advenier et al., 2002; Berg, 2003; Lenz et al., 2003; Ruzzenenti \& Basosi, 2009).

Fundamental factors can be influenced by a series of policy measures, programmes and actions (Fig. 6). Thus, all of the fundamental factors are influenced by fiscal measures, particularly those measures that refer to fuel taxes (special hydrocarbons tax and fuel sale retailer tax) and vehicle taxes (Calthrop et al., 2007; Parry \& Small, 2005; Suter \& Walter, 2001). The measures from Fig. 6 also have particular effects on the fundamental factors (i.e., land use control and planning influence only the length of haul). Increasing the number of night-time operations, the inclusion of freight transport logistics in the $\mathrm{CO}_{2}$ trading system and the use of vehicles with low $\mathrm{CO}_{2}$ intensities can significantly reduce the externalities (McKinnon, 2008). These measures are being implemented or are under consideration, and they can reduce the external costs of freight transport in different ways. In a similar manner, the pertinent governments could design programmes based on good practices, and the freight transport companies could guide the management and operation of the transport systems in the most efficient manner, thus minimising fuel consumption and reducing transport demand (McKinnon, 2007; McKinnon \& Ge, 2004).

\section{Technological advances and measures in vehicles, companies and fuels}

Within the measures adopted by vehicle manufacturers to reduce energy and environmental intensities, such as $\mathrm{CO}_{2}$, pollutant emissions and accidents, it is worth highlighting those

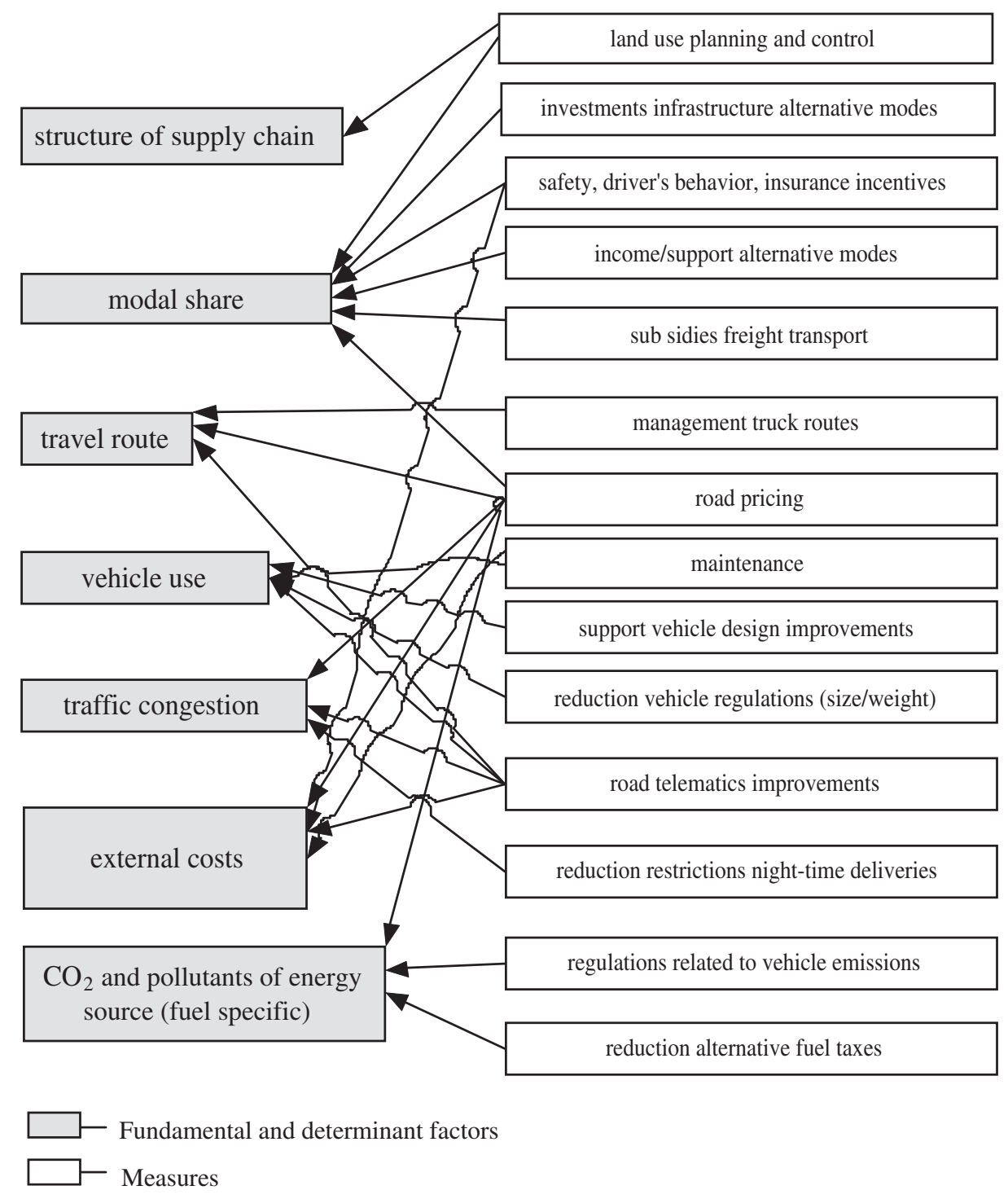

Fig. 6. Policy measures that affect the fundamental factors of freight surface transport. 
measures that have had a direct impact: the technology of engines, tyres, lubricants, manufacturing materials, auxiliary elements and aerodynamics (Advenier et al., 2002; Orasch \& Wirl, 1997). Manufacturers have significantly improved the technology of diesel engines and transmissions, which has enhanced engine efficiency. Through the new electronic injection systems and the introduction of the automatic gear box, engine efficiency has been improved by up to $30 \%$, which has significantly reduced fuel consumption, subsequent emissions and related external costs (Saricks et al., 2003). Similarly, advances have been made in tyre technology, and rolling drag has been reduced. The new synthetic lubricants reduce internal friction in both the engine and transmissions. An adequate use of lubricants also helps to reduce fuel consumption (Ang-Olson \& Schroeer, 2002).

Vehicle manufacturing materials have been improved, and they are now more resistant and lighter (i.e., aluminium and carbon fibre). The use of lighter materials reduces the weight of the tractor head and the trailer, thus improving the load/tare ratio and fuel consumption (Lutsey \& Sperling, 2005). Tare reduction allows for an increased useful load capacity of the vehicle. The auxiliary services of trucks (air conditioning, heating, compressor, hydraulic pump and radiator fan) use a considerable amount of energy. Therefore, measures aimed at reducing the energy consumption of these services have a significant impact on end consumption. Note that advanced materials are not cost-effective in all applications, thus limiting their potential market penetration. For some applications, the fuel savings do not justify the additional cost of aluminium or carbon fibre. The use of electric and/or fuel battery operated auxiliary services can reduce fuel consumption significantly in trains (García, 2005). Finally, through an aerodynamic design, the aerodynamic coefficient, and consequently, the fuel consumption, can be reduced considerably (Burguess \& Choi, 2003).

Ang-Olson \& Schroeer (2002) determined the fuel savings that could be obtained by implementing a series of measures in a medium-duty articulated truck. These savings range from $0.6 \%$ with the automatic tyre inflation system to $8 \%$ by reducing the maximum speed from 100 to $90 \mathrm{~km} / \mathrm{h}$. Improving the aerodynamic profile of a vehicle, that is, of the tractor head and trailer combined, can contribute to a reduction of $7.4 \%$. Vehicle manufacturers estimate that together these measures can reduce fuel consumption by 5-10\% (McKinnon, 2008). These manufacturers' improvements must be accompanied by efficient driving. Otherwise, the considerable research and development efforts of manufacturers will be eclipsed. An adequate driving cycle established through efficient driving programmes can reduce fuel consumption by up to $10 \%$ (INSIA, 2008).

There are other types of measures that depend on the management of the transport company and on the actual road hauliers. A large amount of energy can be saved through efficient driving and idling savings at practically zero cost. This measure is opposed to the above-mentioned measures, which involve a high manufacturing cost (Lutsey, Brodrick, Sperling, \& Oglesby, 2004). To control efficient driving and reduce fuel consumption, truck manufacturers have developed telemetric systems (Baumgartner et al., 2008; Leonardi \& Baumgartner, 2004). The data attached to a vehicle can be accessed at any time during the operation of a truck, and the work performed can be monitored. Through the telemetric system, the transport company can access the data stored in the truck's library, and it can analyse the different parameters that determine the transport operations: vehicle load factor, journeys with no load, use of working time, fuel consumption and deviations from the scheduled timetable. However, telemetric systems can only monitor and convey the performance measurements of the vehicle in real time. An intelligent transportation system (ITS) is needed to inform the driver of congestion in the network so that it can be avoided. An ITS can prevent trucks from travelling on congested roads, which exacerbate fuel consumption, and can also prevent other externalities (Crainic, Gendreau, \& Potvin, 2009).

Because stricter emissions standards are integral to achieving reduced emissions, it would be useful to more thoroughly describe the standards used in the construction of the truck fleet composition. Fig. 7 indicates the fraction of the current truck fleet that was subject to earlier, less-strict, standard and provides an indication of potential future improvements in the truck fleet. The average age of vehicles in the road freight fleet is approximately 5 years, so these vehicles are newer than the passenger gasoline fleet (approximately 8.5 years). Regarding energy consumption and associated $\mathrm{CO}_{2}$ emissions, there is still some margin for improvement because of the consumption constraints in the new EURO V standards introduced in 2008.

In freight transport operations, there are large variations in the amounts of $\mathrm{CO}_{2}$ emitted per energy unit consumed within each mode of transport and between different ones (Lenzen, 1999; Schipper et al., 1997; Van Wee et al., 2005). To obtain a precise idea of the environmental advantages of using alternative fuels, a life cycle analysis (LCA) must be performed (Kaul \& Edinger, 2004; Saari et al., 2007). This type of analysis would encourage the use of biodiesel in diesel trucks and trains because the global carbon cycle of the plants used in the production of the bio fuel captures part of the $\mathrm{CO}_{2}$ (Nanaki \& Koroneos, 2012). There are previous studies that compare the $\mathrm{CO}_{2}$ emissions of biodiesel from waste vegetable with the $\mathrm{CO}_{2}$ emissions of conventional low-sulphur diesel. It is estimated that biodiesel emits approximately $2-16 \mathrm{~g}$ of $\mathrm{CO}_{2}$ equivalent per mega-joule of used fuel, which is less than the 83-95 g emitted by conventional diesel (Woods \& Bauen, 2003). Nevertheless, the production of biodiesel from recycled vegetable oil is very low and does not allow for a more ambitious change to biodiesel. Biodiesel is currently mixed with conventional diesel at $5 \%$ without requiring truck engine modifications. However, truck manufacturers restrict the amount of biodiesel contained in the mix on the grounds that a higher amount could damage the air filters. With more regular engine maintenance, it would be possible to increase the mix up to $30 \%$ (Concawe, Eucar, \& JRC, 2006). There are examples of truck fleets in Spain where most of the trucks operate with high biodiesel mixes. Biodiesel currently makes up a small share of the fuel used by trucks and vans in Spain, and it is not used in other modes of transport (Pérez-Martínez \& Monzón de Cáceres, 2008).

The Spanish government encourages the use of bio-fuels through a special tax rate. However, bio-fuels have a higher production cost, and their retail price is similar to that of conventional diesel. Thus, there is little incentive to shift towards biodiesel.

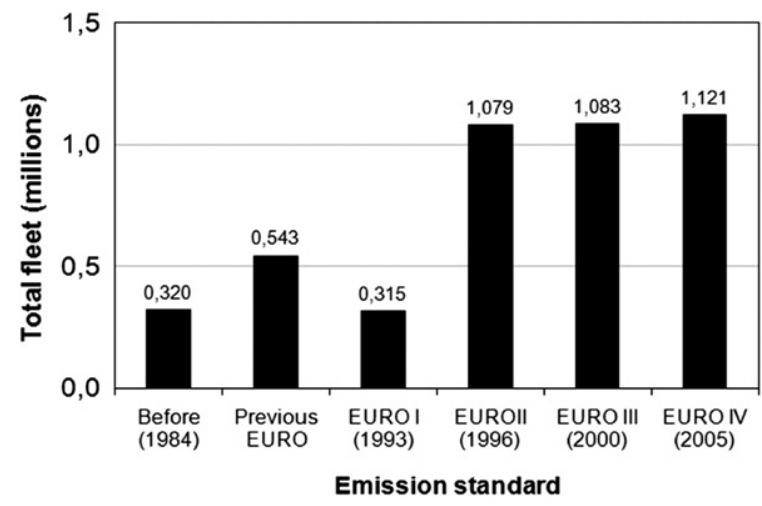

Fig. 7. The heavy-duty vehicle fleet in Spain according toemission standards (2007). 
Furthermore, the use of biodiesel is subject to supply restrictions (both in production and distribution), although the recent investment in new production plants is increasing the supply. The European Directive on renewable fuels established that all fuel must include 5.75\% bio-fuel by 2010 (Biofuels barometer, 2008; Enerma \& CNE, 2008). If road transport increases its use of bio-fuels in the future, rail transport could then lose its competitive edge in terms of having lower $\mathrm{CO}_{2}$ emissions. Rail and pipelines are the only modes of freight transport that use electric energy and, as a result, they are partially fuelled by sources of energy that do not produce $\mathrm{CO}_{2}$, such as hydroelectric, wind, solar and nuclear power (Lakshmanan \& Han, 1997; Schipper et al., 1997). Currently, a large share of the freight transported by rail uses electric energy, and there are specific plans underway to increase that share (RENFE, 2008).

The externalities caused by freight road transport accidents need to be addressed with the specific instruments and measures related to the driver's behaviour, insurance and personal liability incentives, and to the potential of infrastructure and road safety policies (Lindberg, 2001: Proost et al., 2002). Adding personal liability, property damage insurance (as a result of train accidents at rail crossings and train derailments) and workers' compensation payments, American railroads and truck companies paid around $40 \%$ of the total accident costs involving freight trains and trucks (Forkenbrock, 1999, 2001). In freight rail transport, vehicle maintenance related during the execution phase causes represent the higher percent of all rail and track related incidents and accidents (Holmgren, 2005). The most common cause of maintenance related accidents is imperfect communication and information between the maintenance personnel and the operators. In freight road, inadequate vehicle maintenance and transport rule violations, especially lack of permission to perform maintenance work on the highways, are one of the most frequent causes of accidents and affect the right vehicle use (Fig. 6).

\section{Discussion}

In this section we discussed several topics coming from the paper's main results such as the competition between rail and road freight transport, in terms of production of external costs, and the effective measures towards further reduction of the external costs. Supported by the high variability and uncertainty of the external cost estimates, due to limitations of the monetary structure and data availability constraints, and the influence of some other major factors imposed on the freight transport sector from outside, we think that future external costs will be difficult to predict.

In recent years, the road freight transport sector has reduced its external costs considerably. This reduction has been considerably more energetic than in the rail sector, which has been subject to less social pressure to reduce its externalities. This reduction has led to road transport substantially narrowing the gap with rail transport in the generation of externalities per transport unit. The external cost reductions of road transport are present as increased energy efficiency, lower emissions and fewer accidents. Even so, rail freight transport continues to be more efficient than road transport in terms of the generation of externalities. However, the mode of transport with the best environmental performance may not be a viable alternative in many instances. In fact, road transport has a captive market in a large number of niches, such as the last mile, express parcels and "just in time" deliveries. Rail transport can be a viable alternative to road transport when transporting large volumes or long distances. Rail is competitive for very short distance flows of power station coal like in Northern Spanish mining areas. The rail versus road comparisons could be biased as rail would only handle some of the functions of road transport, and generally these are the higher volumes or longer distance transport where road itself has lower external costs than on average. Energetic and environmental impacts of freight surface transportation are usually modelled following average data, which do not reflect the characteristics of specific lines (García, Pérez-Martínez, \& González, 2012; López, Rodríguez, Burón, \& García, 2009). Additionally, rail might be more viable when transporting freight with low added value. There are international experiences that demonstrate the possibility of investing in improved rail freight infrastructure to make rail more competitive for higher value freight. One such example is the US rail model. Since 1980, the US has invested in intermodal terminals, has improved line haul rail corridors and has developed more advanced designs for doublestack container trains, thus leading to growth that has outpaced that of the truck on a percentage basis. The experience of the US rail model runs counter to the experience of most European countries (Vassallo \& Fagan, 2007).

The study confirms that road freight transport is moving in the right direction in terms of external costs per tonne of transported goods. Nevertheless, the study also confirms that there is considerable room for reducing the external costs even further. A number of public measures and policies have recently been developed in Spain to help reduce the externalities of transport. These measures are mainly centred on modal distribution, vehicle load factors and fuel use efficiency. This study reviews these initiatives and considers the possibility of broadening them through more robust measures. It is suggested that the measures recently employed are relatively effective in terms of avoided externality per Euro invested. This study provides a summary of technological advances in vehicles, companies and fuels. It provides first-hand insight into the consequences of the different measures involved in transport. Additionally, it indicates the fundamental factors that ought to be modified to reduce the externalities by as much as possible in the future, thus balancing such reduction with harmonious economic development. However, the main source of the reduction of external costs appears to be the decreasing emissions of new vehicles due to regulation; newer models meet much stricter EU emissions standards for nonglobal warming pollutants. Other countries subject to EURO emissions standards may exhibit similar trends in the external costs of road freight. An interesting question is whether the Spanish road freight sector is leading or lagging the EU in the pace of fleet renewal.

The high variability in the results from studies of other country's external costs is referenced in the paper and attributed, in part, to differences in data availability by country. We discuss this background information and describe the range of external costs estimates in the results section. This paper also discusses the relative contribution of data availability, the uncertainty in key parameters and the consequent unit external costs. Some European data, such as the recent changes in the energy intensity of road and rail freight, appear anomalously large because of unusual data peaks or differences in the data collection methodology (Maibach et al., 2008). Thus, a discussion of the quality of data that are relevant to the freight mode in Spain needs to happen prominently. The original external cost estimates in this paper were based on governmental sources (e.g., accident records and costs). Except for road climate change and rail air pollution costs, the initial estimates adapted existing European literature estimates. Owing to the application of a higher cost per tonne of $\mathrm{CO}_{2}$, the road freight $\mathrm{CO}_{2}$ emission costs per t-km for Spain are slightly higher in this article than those reported by Maibach et al. (2008). The rail freight pollutant emission costs per $\mathrm{t}-\mathrm{km}$ for Spain are lower in this article than in other European studies because Spain has a higher proportion of electric trains.

We found that the external cost estimation is somewhat sensitive to the assumed cost per tonne of pollutant (basically $\mathrm{NO}_{x}$ and $\mathrm{PM}$ ) and the $\mathrm{CO}_{2}$-equivalent emissions. Moreover, research on the external 
cost of freight would benefit from more critical discussion, some sensitivity analyses and/or a justification of the 2,600,16,500 and 25 Euro figures employed by other studies. For instance, the 25 Euro figure that arises as a near-term cost per tonne of $\mathrm{CO}_{2}$ in the $\mathrm{EU}$ Handbook could be considered as a reflection of an emissions price rather than being considered a rate of external marginal cost. The monetary evaluation techniques of transport external costs have some limitations, uncertainties and ethical concerns (Int Panis et al., 2004; Truong, Stefanovich, \& Stirling, 1997). Like it was shown in this paper, environmental valuation results vary over a very wide range of values, yielding a variety of rank orderings for the different external costs. In addition, the values derived for energy and emissions externalities are found to be vulnerable to the possible influence of a price imperative (Stirling, 1997). In the long-term, the value of external costs presented in this paper, which are $17 \%$ of the total operational costs, may understate the total externalities because it underestimates the cost of pollutant and $\mathrm{CO}_{2}$ emissions from fossil fuel combustion. If some of the more extreme scenarios for the effect of transport pollution and climate change on both the natural and built environment eventually materialise, then the values that appear in this paper might, in hindsight, prove to have been too low. There are some risks associated with underestimating the cost of transport pollution and climate change, such as the transport rebound effect, which is based on pollutant and carbon intensity transport modes (Schipper, 2000; Schipper \& Grubb, 2000). During the researched period (1993-2007), surface freight transport in Spain exhibited patterns consistent with the Jevons paradox, where the environmental intensity of transport performance (external cost produced/ transport unit) has steadily declined while total transport demand grew. Externalities could decrease in unitary terms, but the increasing transport demand can increase the total externalities. Technological improvements could increase the amount of resources used in the future (Clark \& York, 2005; York, Ergas, Rosa, \& Dietz, 2011).

Operational efficiencies (i.e., driving techniques) can be available to the rail as well as the road sector, and the international freight railways have indeed recently focused on fuel-saving train operation techniques. Assessment of the potential for externality reduction in Spain would benefit from further research on the uptake of various technologies and on the operational techniques in the rail sector. The uptake of new technologies contradicts the reported decline in the rail modal share. However, this study's primary results suggest that increasing Spain's rail freight share would reduce the external costs of freight transportation.

There are other major factors, such as the economic context, the production structure and the structure of the territory, which particularly affect the behaviour of the freight transport sector and the subsequent externalities (Cuddihy, Kennedy, \& Byer, 2005). These factors are imposed on the sector from outside and give the sector limited room to manoeuvre in reducing external costs. For example, the spatial structure of the supply chain has an enormous impact on the number of trips made and thus on the externalities produced (Browne et al., 2005). The governing forces of the economic market and the policies and measures implemented by governments particularly influence the fundamental factors of the freight transport system (mainly of an economic nature). The empirical observations obtained in the results section of this study, together with their interrelations, provide a guide for planning changes to the transport system. This study can help analysts, managers and policy-makers in their efforts to achieve a more sustainable transport system in the future.

\section{Acknowledgements}

This study was conducted within the framework of a co-operation agreement between the Francisco Corell Foundation and, through the
"Armelio Ochoa" chair, the Transport Research Centre of Universidad Politécnica de Madrid (TRANSYT). Under this agreement, the "Armelio Ochoa" chair was established to conduct research related to road transport in Spain and to disseminate its findings by organising conferences and events related to the sectors involved.

\section{References}

ADIF. (2009). Declaración sobre la red 2008. Madrid: Publicaciones del Administrador de Infraestructuras Ferroviarias.

Advenier, P., Boisson, P., Delarue, C., Douaud, A., Girard, C., \& Legendre, M. (2002) Energy consumption and $\mathrm{CO}_{2}$ emissions of road transportation: comparative analysis of technologies and fuels. Energy and Environment, 13(4-5), 631-646.

AFFORD. (2001). Acceptability of fiscal and financial measures and organisationa requirements for demand management. Final report for publication. Helsinki: Government Institute for Economic Research.

Ang-Olson, J., \& Schroeer, W. (2002). Energy efficiency strategies for freight trucking. Potential impact on fuel use and greenhouse gas emissions. Transportation Research Record, 1815, 11-18.

Aparicio, F., Burón, J. M., Páez, F. J., López, J. M., Alegre, J. A., Gómez, A., et al. (2005) Impacto del Transporte de mercancías sobre el medio ambiente y el consumo energético. Estudios de Construcción y Transportes, 103, 63-96.

Ban-Weiss, G. A. McLaughlin, J. P., Harley, R. A., Lunden, M. M., Kirchstetter, T. W. Kean, A. J., et al. (2008). Long-term changes in emissions of nitrogen oxides and particulate matter from on-road gasoline and diesel vehicles. Atmospheric Environment, 42, 220-232.

Baumgartner, M., Leonardi, J., \& Krusch, O. (2008). Improving computerized routing and scheduling and vehicle telematics: a qualitative survey. Transportation Research Part D, 13, 377-382.

Berg, W. (2003). Legislation for the reduction of exhaust gas emissions. In D. Gruden (Ed.), Traffic and environment, the handbook of environmental chemistry (pp. 175253). Berlin Heidelberg, New York: Springer.

Betancor, O., \& Nombela, G. (2003). Unification of accounts and marginal costs for transport efficiency. Deliverable 8. Annex 3: the pilot account for Spain. Leeds. European Commission and Institute for Transport Studies.

Bickel, P., Friedrich, R., Link, H., Stewart, L., \& Nash, C. (2005). Introducing environmental externalities into transport pricing: measurement and implications. Transport Reviews, 26, 389-415.

Biofuels barometer. (2008). 7.7 MTOE consumed in EU in 2007. Systèmes Solaires, 185, 49-66.

deBlaeij, R. J., Florax, G. M., Rietveld, P., \& Verhoef, E. (2003). The value of statistical life in road safety: a meta-analysis. Accident Analysis and Prevention, 35(6), 973-986.

Browne, M., Allen, J., \& Rizet, C. (2006). Assessing transport energy consumption in two product supply chains. International Journal of Logistics Research and Applications, 9, 237-252.

Browne, M., Rizet, C., Anderson, S., Allen, J., \& Keïta, B. (2005). Life cycle assessment in the supply chain: a review and case study. Transport Reviews, 25, 761-782.

Burgard, D. A., Bishop, G. A., \& Stedman, D. H. (2006). Remote sensing of in-use heavy-duty diesel trucks.Environ. Sci. Technol, 40, 6938-6942.

Burgess, S. C., \& Choi, J. M. J. (2003). A parametric study of the energy demands of car transportation: a case study of two competing commuter routes in the UK. Transportation Research Part D, 8(1), 21-36.

Calthrop, E., de Borger, B., \& Proost, S. (2007). Externalities and partial tax reform: does it make sense to tax road freight transport? Journal of Regional Science, 47 , $721-752$

CAPRI. (1998). Concerted action on transport pricing research integration. Final report Annex C. Road transport pricing issues. Leeds. University of Leeds.

Clark, B., \& York, R. (2005). Carbon metabolism: global capitalism, climate change and the biospheric rift. Theory and Society, 34(4), 391-428.

Concawe, Eucar, \& JRC. (2006). Well-to-wheel analysis of future automotive fuels and power-trains in the European context (Brussels).

Crainic, T. G., Gendreau, M., \& Potvin, J. I. (2009). Intelligent freight-transportation systems: assessment and the contribution of operations research. Trans portation Research Part, C17, 541-557.

Cuddihy, J., Kennedy, C., \& Byer, P. (2005). Energy use in Canada: environmental impacts and opportunities in relationship to infrastructure systems. Canadian Journal of Civil Engineering, 32, 1-15.

Dallmann, T. R., \& Harley, R. A. (2010). Evaluation of mobile source emissions trends in the United States. Journal of Geophysical Research, 115, 14305-143017.

ECMT. (2007). Cutting transport CO2 emissions: What progress? Paris: OECD publications.

EEA. (2006). Transport and environment: Facing a dilemma. TERM 2005. Copenhagen: European Environmental Agency.

ENERMA, \& CNE. (2008). Energía y medio ambiente en España. Madrid: Centro de Publicaciones del Ministerio de Medio Ambiente y Medio Rural y Marino.

European Council. (2006). Directiva 2006/38/CE por la que se modifica la Directiva 1999/62/CE relativa a la aplicación de gravámenes a los vehículos pesados de transporte de mercancías por la utilización de determinadas infraestructuras. DiarioOficial de la Unión Europea L, 157, 8-23.

Forkenbrock, D. (1999). External costs of intercity truck freight transportation. Transportation Research Part A, 33, 505-526. 
Forkenbrock, D. (2001). Comparison of external costs of rail and truck freight transportation. TransportationResearchPart A, 35(4), 321-337.

García, A. (2005). El tren de alta velocidad no es un depredador de energía. DYNA, 5(1), 33-38.

García, A., Pérez-Martínez, P. J., \& González, I. (2012). Consumo energético del transporte de mercancías por ferrocarril y carretera en España: caso de estudio de porta-vehículos y graneles petroquímicos. La Habana, Cuba: XXXIII Convención Panamericana de Ingenierías UPADI.

GRACE. (2006). Generalization of research on accounts and cost estimation. Deliverable D3 marginal costs case studies for road and rail transport. Leeds: University of Leeds.

Gruden, D. (2003). Traffic and environment, the handbook of environmental chemistry. Berlin Heidelberg, New York: Springer.

Haney, Q., O'Mahony, M., \& Gibbons, E. (2005). External costs associated with interregional transport. Transportation Research Record, 1659, 79-86.

HEATCO. (2005). Developing harmonised European approaches for transport costing and project assessment. Deliverable 2: state-of-the-art in project assessment. Stuttgart: University of Stuttgart.

Hernández-Martínez, F. (2006). La producción de energía eléctrica en España: análisis económico de la actividad tras la liberación del sector eléctrico. Documento de Trabajo 290/2006. Madrid, Spain: Fundación de las Cajas de Ahorro.

Holmgren, M. (2005). Maintenance related losses at the Swedish Rail. Journal of Ouality in Maintenance Engineering, 11(1), 5-18.

IMPRINT. (2005). Implementing Pricing Policies in Transport: Phasing and Packaging. Practice and experience with implementing transport pricing reform in heavy goods transport in Switzerland (Brussels).

INE. (2008). Contabilidad Nacional de España. Valor añadido bruto a precios básicos: precios corrientes. Madrid: InstitutoNacional de Estadística.

INFRAS-IWW. (2004). External costs of transport: Accidents, environmental and congestion costs of transport in Western Europe. Zurich Karlsruhe: University of Karlsruhe.

INSIA. (2008). Informe técnico de MAN vehículos industriales (España). Madrid: Universidad Politécnica.

Int Panis, L., De Nocker, L., Cornelis, E., \& Torfs, R. (2004). An uncertainty analysis of air pollution externalities from road transport in Belgium in 2010. Science of the Total Environment, 334-335, 287-298.

Janic, M. (2007). Modelling the full costs of an intermodal and road freight transport network. Transportation Research Part D, 12, 33-44.

Janic, M. (2008). An assessment of the performance of the European long intermodal freight trains (LIFTS). Transportation Research Part A, 42, 1326-1339.

Johnstone, N., \& Karousakis, K. (1999). Economic incentives to reduce pollution from road transport: the case for vehicle characteristics taxes. Transport Policy, 6, 99-108.

Kaul, S., \& Edinger, R. (2004). Efficiency versus cost of alternative fuels from renewable resources: outlining decision parameters. Energy Policy, 32, 929-935.

Kühlwein, J., \& Friedrich, R. (2005). Traffic measurements and high performance modeling of motorway emission rates. Atmospheric Environment, 39, 57225736.

Lakshmanan, T. R., \& Han, X. (1997). Factors underlying transportation $\mathrm{CO}_{2}$ emissions in the U.S.A.: a decomposition analysis. Transportation Research Part D, 2, $1-15$.

Lemp, J. D., \& Kockelman, K. M. (2008). Quantifying the external costs of vehicle use: evidence from America's top-selling light-duty models. Transportation Research Part D, 13, 491-504.

Lenzen, M. (1999). Total requirements of energy and greenhouse gases for Australian transport. Transportation Research Part D, 4, 265-290.

Lenz, H. P., Prüller, S., \& Gruden, D. (2003). Means of Transportation and their effect on the environment. In D. Gruden (Ed.), Traffic and environment, the handbook of environmental chemistry (pp. 107-173). Berlin Heidelberg, New York: Springer.

Léonardi, J., \& Baumgartner, M. (2004). $\mathrm{CO}_{2}$ efficiency in road freight transportation: status quo, measures and potential. Transportation Research Part D, 9, 451-464.

Lindberg, G. (2001). Trafficinsurance and accident externality charges. Journal of Transport Economics and Policy, 35(3), 399-416.

Link, H., \& Nilsson, J. E. (2005). Infrastructure. In C. Nash, \& B. Matthews (Eds.), Measuring the marginal social cost of transport infrastructure (pp. 49-83). Oxford: Elsevier.

López, I., Rodríguez, J., Burón, J. M., \& García, A. (2009). A methodology for evaluating environmental impacts of railway freight transportation policies. Energy Policy, 37, 5393-5398.

Lutsey, N., Brodrick, C., Sperling, D., \& Oglesby, C. (2004). Heavy-duty truck idling characteristics. Transportation Research Record, 1880, 29-38.

Lutsey, N., \& Sperling, D. (2005). Energy efficiency, fuel economy, and policy implications. Transportation Research Record, 1941, 8-17.

Maibach, M., Schreyer, C., Sutter, D., van Essen, H. P., Boon, B. H., et al. (2008) Handbook on estimation of external costs in the transport sector. Brussels: European Commission.

McKinnon, A. C. (2007). Decoupling of road freight transport and economic growth trends in the UK: an exploratory analysis. Transport Reviews, 27(1), 37-64.

McKinnon, A. C. (2008). $\mathrm{CO}_{2}$ emissions from freight transport in the UK. Report prepared for the Climate Change Working Group for the Commission for Integrated Transport. Edimburg: LRC Heriot-Watt University.

McKinnon, A. C., \& Ge, Y. (2004). Use of a synchronized vehicle audit to determine opportunities for improving transport efficiency in a supply chain. International Journal of Logistics, 7, 219-238.
MFO. (2007). Observatorio de precios del transporte de mercancías por carretera en vehículos pesados. Madrid: Centro de Publicaciones Secretaría General Técnica Ministerio de Fomento.

MFO. (2008a). Encuesta Permanente de Transporte de Mercancías por Carretera 2007 y 1994. Madrid: Centro de Publicaciones de la Secretaría General Técnica del Ministerio de Fomento.

MFO. (2008b). Los transportes y los servicios postales. Informe anual 2007. Madrid: Centro de Publicaciones de la Secretaría General Técnica del Ministerio de Fomento.

MI. (2008). Anuario Estadístico general 2007. Madrid: Centro de Publicaciones de la Dirección General de Tráfico del Ministerio del Interior.

Monzón, A., Fernández, A., \& Jordá, P. (2007). Cuenta Económica y Socioambiental del Transporte Terrestre de Viajeros en la Comunidad de Madrid. Madrid: TRANSYT Universidad Politécnica de Madrid.

Monzón, A., Vassallo, J. M., Di Cimmo, F., \& Pérez-Martínez, P. (2008). META: Modelo español de tarificación de carreteras. Madrid: TRANSyT Universidad Politécnica de Madrid.

Nanaki, E. A., \& Koroneos, C. J. (2012). Comparative LCA of the use of biodiesel, diesel and gasoline for transportation. Journal of Cleaner Production, 20, 14-19.

Nash, C. (2007). Road pricing in Britain. Journal of Transport Economics and Policy, 41(1), 135-147.

Nash, C., \& Matthews, B. (2005). Measuring the marginal social cost of transport. Oxford: Elsevier

Navrud, S. (2002). The state-of-the-art on economic valuation of noise. Oslo.

OFE. (2009). Observatorio del Ferrocarril en España. Transporte de mercancías. Madrid: Fundación Española de los Ferrocarriles.

Orasch, W., \& Wirl, F. (1997). Technological efficiency and the demand for energy (road transport). Energy Policy, 25, 1129-1136.

Parry, I. W. H., \& Small, K. A. (2005). Does Britain and the United States have the right gasoline tax? American Economic Review, 95, 1276-1289.

Pérez-Martínez, P. J. (2009). The vehicle approach for freight road transport energy and environmental analysis in Spain. European Transport Research Review, 1(2), 75-85.

Pérez-Martínez, P. J. (2010). Freight transport, energy use and emission trends in Spain. Transport Research Record, 2191, 16-22.

Pérez-Martínez, P. J. Energy consumption and emissions from the road transport in Spain: a conceptual approach. Transport Journal, in press.

Pérez-Martínez, P. J., \& Monzón de Cáceres, A. (2008). Informe sobre transporte y medio ambiente. Trama 2008. Madrid: Centro de Publicaciones Secretaría General Técnica Ministerio de Medio Ambiente.

Pérez-Martínez, P. J., \& Sorba, I. (2010). Energy consumption of passenger land transport modes. Energy and Environment, 21(6), 577-600.

Pimentel, D., Pleasant, A., Barron, J., Gaudioso, J., Pollock, N., Chae, E., et al. (2004). US energy conservation and efficiency: benefits and costs. Environment, Development and Sustainability, 6, 279-305.

Proost, S., Van Dender, K., Courcelle, C., De Borger, B., Peirson, J., Sharp, D., et al. (2002). How large is the gap between present and efficient transport prices in Europe? Transport Policy, 9, 41-57.

Quinet, E. (2004). A meta-analysis of Western European external costs estimates. Transportation Research Part D, 9, 456-476.

RECORD-IT. (2001). Real cost reduction of door-to-door intermodal transport. Deliverable 4: External cost calculation for selected corridors. Stuttgart: University of Stuttgart.

RENFE. (2008). Annual report. Madrid: Dirección de Comunicación Corporativa y Relaciones Externas.

REVENUE. (2006). Use of revenues from transport pricing. Deliverable 6, synthesis and policy conclusions. Rome: Institute of Studies for the Integration of Systems.

Rothengatter, W. (2001). How good is first best? Marginal cost and other pricing principles for user charging in transport. Transport Policy, 10, 121-130.

Ruzzenenti, F., \& Basosi, R. (2009). Evaluation of the energy efficiency evolution in the European road freight transport sector. Energy Policy, 37, 4079-4085.

Saari, A., Lettenmeier, M., Pusenius, K., \& Hakkarainen, E. (2007). Influence of vehicle type and road category on natural resource consumption in road transport. Transportation Research Part D, 12, 23-32.

Saricks, C., Vyas, A. D., Stodolsky, F., \& Maples, J. D. (2003). Fuel consumption of heavy duty trucks: potential effect of future technologies for improving energy efficiency and emissions. Transportation Research Record, 1842, 9-19.

Schipper, L. (2000). On the rebound: the interaction of energy efficiency, energy use and economic activity. An introduction. Energy Policy, 28(6-7), 351-353.

Schipper, L., \& Grubb, M. (2000). On the rebound? Feedback between energy intensities and energy uses in IEA countries. Energy Policy, 28(6-7), 367-388.

Schipper, L., Scholl, L., \& Price, L. (1997). Energy use and carbon emissions from freight in 10 industrialized countries: an analysis of trends from 1973 to 1992. Transportation Research Part D, 2, 57-76.

Singh, A., Gangopadhyay, S., Nanda, P. K., Bhattacharya, S., Sharma, C., \& Bhan, C. (2008). Trends of greenhouse gas emissions from the road transport sector in India. Science of the Total Environment, 390, 124-131.

Smit, R., Ntziachristos, L., \& Boulter, P. (2010). Validation of road vehicle and traffic emission models - a review and meta-analysis. Atmospheric Environment, 44, 2943-2953.

Stirling, A. (1997). Limits to the value of external costs. Fuel and Energy Abstracts, 38(5), 353.

Suter, S., \& Walter, F. (2001). Environmental pricing-theory and practice. The Swiss policy of heavy vehicle taxation. Journal of Transport Economics and Policy, 35(3), 381-397. 
Tol, R. (2005). The marginal damage costs of carbon dioxide emissions: an assessment of the uncertainties. Energy Policy, 33, 2064-2074.

Torchio, M. F., \& Santarelli, M. G. (2010). Energy, environmental and economic comparison of different powertrain/fuel options using well-to-wheels assessment, energy and external costs - European market analysis. Energy, 35, 4156-4171.

Truong, T. N., Stefanovich, E. V., \& Stirling, A. (1997). Limits to the value of external costs. EnergyPolicy, 25(5), 517-540, (24).

UE. (1995). Hacia una tarifación equitativa y eficaz del transporte - opciones para la internalización de costes externos del transporte en la Unión Europea, Libro Verde, COM 691 final. Bruselas: Unión Europea.

UE. (1998a). Informe del Grupo de Alto Nivel sobre tarifación de las infraestructuras del transporte. Informe a la Comisión de Junio 1998. Bruselas: Unión Europea.

UE. (1998b). Tarifas justas por el uso de infraestructuras: estrategia gradual para un marco común de tarifación de transporte en la UE, Libro Blanco. Bruselas: Unión Europea.

UE. (1999). Directiva "Eurovignette" n. 62. Bruselas: Unión Europea.

UE. (2001). Política de Transporte Europeo, Libro Blanco. Bruselas: Unión Europea.

UE. (2006). Directiva "Eurovignette" n. 38. Bruselas: Unión Europea.

UIC. (2009). Safety databasereport 2009. Paris: Union Internationale des Chemins de Fer

UNITE. (2003). Unification of accounts and marginal costs for transport efficiency. Final Report. Leeds: University of Leeds.
Van Wee, B., Janse, P., \& Van Den Brink, R. (2005). Comparing energy use and environmental performance of land transport modes. Transport Reviews, 25, $3-24$.

Vanek, F. M., \& Campbell, J. B. (1999). UK road freight energy use by product: trends and analysis from 1985 to 1995. Transport Policy, 6, 237-246.

Vanek, F. M., \& Morlok, E. K. (2000). Improving the energy efficiency of freight in the United States through commodity-based analysis: justification and implementation. Transportation Research Part D, 5, 11-29.

Vassallo, J. M., \& Fagan, M. (2007). Nature or nurture: why do railroads carry greater freight in the United States than in Europe? Transportation, 34, 177-193.

Vassallo, J. M., Solís, C., Pérez-Martínez, P. J., \& Pérez de Villar, P. (2009). Balance económico, fiscal, social y medio ambiental del sector transporte de mercancías en España. Madrid: Fundación Francisco Corell.

Woods, J., \& Bauen, A. (2003). Technological status review and carbon abatement potential of renewable transport fuels in the UK. London: Imperial College London- Centre for Energy Policy and Technology.

Yanowitz, J., McCormick, R. L., \& Graboski, M. S. (2000). In use emissions from heavy-duty diesel vehicles. Environmental Science E Technology, 34(5), 729-740.

York, R., Ergas, C., Rosa, E. A., \& Dietz, T. (2011). It is a material world: trends in material extraction in China, India, Indonesia, and Japan. Theory and Society, 34(4), 391-428. 